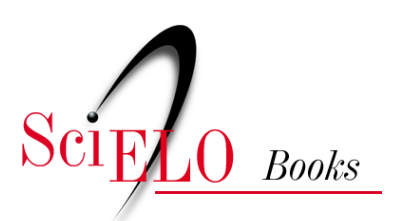

\title{
Único e simultaneamente diverso
}

\author{
José Carlos da Exaltação Torres
}

\section{SciELO Books / SciELO Livros / SciELO Libros}

TORRES, J.C.E. Único e simultaneamente diverso. In: Cadastro Único: tecnologia de reclassificação social [online]. Salvador: EDUFBA, 2016, pp. 125-182. ISBN: 978-65-5630-011-5. https://doi.org/10.7476/9786556300115.0010.

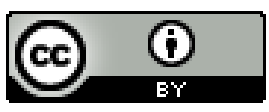

All the contents of this work, except where otherwise noted, is licensed under a Creative Commons Attribution 4.0 International license.

Todo o conteúdo deste trabalho, exceto quando houver ressalva, é publicado sob a licença Creative Commons Atribição 4.0. 


\section{ÚNICO E SIMULTANEAMENTE DIVERSO}

Os dados até aqui apresentados demonstram que a construção do Cadastro Único resultou de diversas operações de natureza técnica para definição e conceituação do público específico (beneficiários) de um conjunto de programas sociais focalizados, os quais representam uma escolha política do governo brasileiro no enfrentamento da pobreza no país. Cada um dos diferentes programas implementados atendia a determinadas situações de vulnerabilidade previamente desenhadas e sobre elas desenvolvia seus próprios mecanismos de identificação e seleção das famílias às quais pretendia beneficiar. Assim, embora visassem um mesmo público e sustentassem finalidades similares, esses programas foram concebidos, implantados e mantidos de forma apartada. Com base nesse quadro, o presente capítulo discute as dificuldades e contradições que marcaram o processo de implantação e os primeiros anos de vigência do Cadastro Único, ao qual se atribuía a tarefa de "garantir a unicidade e a integração [dos dados] [...] e a racionalização do processo de cadastramento pelos diversos órgãos públicos”. (BRASIL, 2001e, Art. $2^{\circ}$ ) Pode-se observar que os problemas identificados nesse processo eram provenientes de diversos fatores, mas dentre estes alguns merecem especial destaque, como a própria fragmentação dos programas de transferência de renda e a estrutura do relacionamento estabelecido entre os órgãos federais, gestores desses programas, e a administração pública municipal, responsável pela execução dos mesmos.

Tomando a Bahia como exemplo, estado que guarda características importantes referentes ao processo de implantação de programas nacionais de 
transferência de renda ${ }^{34}$ e que, como se verá em breve, em alguns momentos, ilustrou referências para planejamento do processo cadastral, pode-se ter uma noção de como se desenvolveu a dinâmica de implantação do Cadastro Único no Brasil.

Importa ressaltar, todavia, que buscar na experiência baiana elementos para abrir a presente discussão não implica em opção metodológica por um estudo de caso, mas na consideração de que as características aí verificadas oferecem pistas para a compreensão do processo global. Com esse intuito, foram realizadas entrevistas de caráter exploratório com representantes de duas instituições que desempenharam papéis relevantes na implantação do Cadastro Único no estado: o CRH-UFBA e a CEF. A primeira entrevista se deu no CRH-UFBA e a segunda na CEF, identificadas doravante como Ent.1 e Ent.2, respectivamente.

O cadastramento das crianças e adolescentes que compunham o público-alvo do PETI no estado da Bahia se deu a partir de um convênio firmado entre o Governo do Estado, representado na SETRAS, e o CRH-UFBA. Desde 1996, em atenção ao "Compromisso" firmado nacionalmente pela erradicação do trabalho infantil, criou-se na Bahia uma Comissão Interinstitucional, presidida pela SETRAS e integrada por representantes da Secretaria da Saúde, Justiça e Direitos Humanos, Assistência Social, Delegacia Regional do Trabalho (DRT), Fundo das Nações Unidas para a Infância (UNICEF) e outros. (BAHIA, 1996) Composta inicialmente por $11 \mathrm{mem}$ bros, entre representantes dos governos estadual e federal e do UNICEF, posteriormente essa Comissão foi aditada de representantes de entidades da sociedade civil, como o Movimento de Organização Comunitária (MOC) e a Federação dos Trabalhadores na Agricultura (FETAG). (BAHIA, [199-?]; RAMOS; NASCIMENTO, 1997) A Comissão tinha por incumbência "elaborar o Projeto de Erradicação do Trabalho Infantil na Região Sisaleira” do estado (BAHIA, 1996, Art. 1ํ) (o qual fora ampliado à Região das Pedreiras). A pesquisa realizada na UFBA para esse programa deu-se, então, articulada a essa Comissão. (CAMPOS, 1998)

34 Como se viu, ao lado de Pernambuco, a Bahia foi contemplada com a segunda etapa de implantação do PETI, em 1997, que representa o primeiro programa nacional focalizado de transferência de renda instituído no Brasil. (No ano de lançamento, em 1996, o Programa foi implantado como um projeto piloto em Mato Grosso do Sul e, em 1997, foi ampliado para os canaviais de Pernambuco e para a Região do Sisal e das Pedreiras na Bahia). 
A Universidade Federal da Bahia (UFBA), através do CRH, tornou-se, então, responsável pela realização da pesquisa e pelo processamento dos dados, a partir dos quais se faria a seleção dos beneficiários do Programa. O Centro de Processamento de Dados (CPD) da Universidade gerava o banco de dados que serviria de base para o Programa. Com base nesse banco de dados e observando os critérios do programa, os pesquisadores identificavam os potenciais beneficiários e geravam uma relação de nomes encaminhada à SETRAS, a qual transmitia aos municípios as informações para a inserção das famílias.

[...] depois de todas as pesquisas era gerado um banco, tudo aqui era processado, inclusive, pelo CPD, que também fazia parte. Gerava um banco e esse banco era passado pra SETRAS, [...] a gente já passava sinalizando pra SETRAS quais as famílias seriam beneficiadas, que estariam dentro do perfil, porque a gente cadastrava todas, mas nem todas estavam dentro do perfil. (Ent. 1)

Ramos e Nascimento (1997) afirmam que as pesquisas realizadas pela Universidade tinham abrangência censitária e não se limitavam à identificação do público-alvo do Programa, produzindo informações acerca das condições socioeconômicas da população pesquisada, de forma a munir o Poder Público de informações mais amplas para a adoção de medidas em favor da melhoria das condições de vida dessa população. Mas, segundo as entrevistadas, após modificações na estrutura do Programa, advindas do governo federal, a cobertura limitou-se ao atendimento de metas, e, assim, a coleta de dados correspondia a amostras definidas em cada município, referentes a localidades específicas. A definição dessas áreas estava condicionada à deliberação de reuniões realizadas entre a Comissão Interinstitucional, a administração local, a UFBA e organizações da sociedade civil local. Definidas as áreas, o Município disponibilizava um agente local para guiar os pesquisadores às comunidades previamente selecionadas.

[...] a gente passou a atender em cima de metas, trabalhar em cima de metas, então não foi mais possível fazer censo [...] Então qual foi a estratégia aí pra atender: a gente ia para os municípios, fazia reuniões com a sociedade reunida, tanto representação do Poder Público, sociedade civil, estabelecia, combinava com eles onde existia o maior foco, fazia um recorte, [...] prefeitura, associação, representação da sociedade ci- 
vil, sindicatos, né, todas entidades, principalmente ligadas à questão do trabalho, ligada à questão da criança, principalmente, [...] a gente definia com os municípios quais as áreas seriam cadastradas, aí naquela área que era definida, a gente de fato fazia o censo, entendeu, já não cobria mais o município como um todo como era antes, [...] a gente tinha até um suporte do município, de ter alguém para orientar, acompanhar a gente, ser, vamos dizer, o localizador. (Ent. 1)

Em relatório de Auditoria publicado pelo TCU sobre o PETI em todo o Brasil, referente ao período 1996-20oo, a pesquisa realizada pela UFBA foi destacada como um "aspecto positivo" do Programa, no que tange à “identificação e seleção do público alvo”. (BRASIL, 2001k) O TCU verificou à época, que, embora estejam mapeados os focos de trabalho infantil no país, em geral, "não existem dados exatos sobre a quantidade de crianças no trabalho infantil, nem critérios uniformes entre os municípios para a inclusão destas crianças no Programa”. (BRASIL, 2001k, p. 10) Assim, segundo o Tribunal, a Bahia figurava como uma das poucas experiências que podiam servir de referência nacional no processo de cadastramento de crianças e adolescentes para o PETI, com informações diversificadas e consistentes, a partir das quais a seleção se adequava aos requisitos do Programa e se eximia de ingerências políticas locais.

A adoção do Cadastro Único a partir de 2001 deveria, em tese, tornar desnecessário esse trabalho de assessoramento da UFBA, porque seria criada uma base de dados nacional, sob coordenação do governo federal e de responsabilidade operacional da CEF. Mas, a despeito dessas novas condições, manteve-se a necessidade do governo de ter o acompanhamento da Universidade a esse processo.

A gente ainda mantinha esse convênio, o Estado mantinha o nosso serviço, e a gente cadastrava e ao mesmo tempo também passava pro município, pra que o município inserisse já dentro do cadastramento único. Só que, lá na ponta, era complicadíssimo. (Ent. 1)

Uma das causas das complicações a que se refere a entrevistada é que, àquela época, já estava em vigor o Programa Bolsa Escola, vinculado à área de Educação. (BRASIL, 2001h) O PETI, por sua vez, embora constituísse uma "ação interministerial”, estava vinculado à Assistência Social. O Bolsa Escola tinha o seu próprio cadastro, Cadastro do Bolsa Escola (CadBES), 
processado pela CEF, sem qualquer interação com o cadastro do PETI. ${ }^{35}$ Consideradas as disputas políticas inerentes à organização distributiva da Administração Municipal, esse fato se tornou um dificultador para a implementação de um Cadastro Único, que intentava realizar um "desenvolvimento integrado da sistemática de coleta de dados e informações” nos municípios de todo o país. (BRASIL, 2001a) Além disso, os municípios não tiveram tempo para se adaptar às novas determinações, nem mesmo para entendê-las por inteiro. As secretarias municipais das diferentes áreas continuavam a visar o seu público no cadastramento, voltadas para a execução dos programas específicos que lhes diziam respeito. A prorrogação do convênio entre o CRH-UFBA e o governo estadual busca exatamente suprir essa lacuna na garantia de continuidade do processo de seleção dos beneficiários do PETI, inclusive porque o Cadastro Único foi concebido numa relação direta entre o governo federal e os municípios, sem ter inicialmente a participação do estado. Considerando aspectos relativos à unificação dos programas a entrevistada considera:

Primeiro, foi a coisa de cima, eles não foram preparados, [...] a própria coleta, né, que jogaram um instrumento [...] imenso, [...] Educação não abria mão do seu, a Educação cadastrava lá as suas famílias que eram atendidas na escola que ela matriculava. [...] cada um com o seu pedaço, porque era assim, eles no próprio município não se entendiam. [...] além de ter essa dificuldade da falta de integração, de cada qual com o seu pedaço, Social com o seu pedaço, Saúde com o seu pedaço, Educação, [...] [às vezes] num município uma família era cadastrada quatro, cinco vezes, [...] e aí pra jogar isso no sistema era complicadíssimo. (Ent.1)

A informatização do processo cadastral demandava conhecimentos e recursos dos quais os municípios não dispunham, principalmente pessoal especializado para tratar os dados. O sistema anterior, que pertencia ao Bolsa Escola, já era informatizado, mas não era operado pelo município. Então, não havia qualquer experiência nesse sentido. As dificuldades se acentuavam pelo fato de, na fase da implantação, o software do Cadastro estar sujeito a alterações contínuas (Ent.1). E, por outro lado, em se tratando de

35 O CadBES, aliás, é apontado como sendo o primeiro cadastro nacional para um programa de transferência de renda, importância estendida ao Bolsa Escola, ao qual servia. (Ent. 2) 
conteúdo, o banco de dados pré-existente pouco contribuía para a alimentação do novo cadastro, porque não havia identificação entre os sistemas e os formulários não se compunham de campos correspondentes. O cadastro do PETI era bastante simplificado e não contemplava todos os membros da família, não havendo, portanto, como migrar eletronicamente os dados de um cadastro para o outro. A sua principal utilidade estava na geração de uma listagem com os nomes dos potenciais beneficiários do Programa, a partir do que as prefeituras podiam contatar diretamente as respectivas famílias beneficiadas. Assim, a unificação do cadastro exigia que todo o trabalho tivesse mesmo que ser reiniciado.

A obrigatoriedade de uso imediato do Cadastro Único como única via de acesso aos programas sociais federais (BRASIL, 2001e) contribuiu bastante para se estabelecer essa confusão em todo o processo, e mesmo sobre o entendimento acerca do que representava aquele Cadastro. Isso se somou à falta de infraestrutura e de preparo técnico, características dos municípios. O Cadastro começou a ser utilizado em setembro de 2001 (BRASIL, 2001e), época em que entrava em vigor mais um programa do governo federal, o Bolsa Alimentação. (BRASIL, 20o1i) Com este, mais uma área de governo entrava na disputa pelo cadastramento: a Saúde. E talvez com um agravante, porque, como se viu acima, o cadastro utilizado para o Bolsa Alimentação, em sua fase inicial, foi o do SUS, o que obrigava os municípios a operarem simultaneamente mais de um cadastro.

[...] quando começou o cadastro [único], como não tinha ainda uma ideia [do] objetivo do cadastro [...], a força maior dele era pra cadastrar as famílias pra receber o benefício. Então o que é que acontecia, quando chegava até os formulários desse beneficio, era assim, cada secretaria, buscando cadastrar seu público alvo. Apesar de o nome ser 'único', na prática, não existia integração entre as secretarias, cada uma queria o seu pedaço. (Ent. 2)

A Caixa Econômica era a instituição responsável por distribuir os formulários do Cadastro entre os municípios, em quantidade correspondente às estimativas de pobreza definidas pelos indicadores do governo federal. Como os municípios estavam condicionados a essa estimativa, e diante da falta de clareza em relação à unificação cadastral, o esforço das secretarias era para garantir a cobertura do seu público, o que gerava conflitos institucionais. Por conta disso, a CEF atuou também como uma espécie de "agente 
mediador" do entendimento entre as secretarias, para que os formulários chegassem a todas elas. Não se tratava de corrigir a separação, mas de garantir um mínimo de cotização.

[...] quem fazia a entrega, solicitação de formulário, fazia a entrega e distribuição, era a Caixa, [...] era divulgado a família, a estimativa de famílias pobres, aí vamos dizer, determinado município tem direito a mil formulários, e a gente mandava os mil formulários, quando chegavam os mil formulários no município [...] determinada secretaria pegava os mil formulários, e a outra secretaria que queria cadastrar o público alvo dela? Ficava sem formulário. E aí ligava pra gente, pra gente intermediar com a secretaria pra poder dar uma parte do formulário pra outra secretaria. (Ent. 2)

Essas dificuldades eram decerto acompanhadas ou já previstas pelo governo federal, tanto que, em outubro de 2001, foi criado o Grupo de Trabalho envolvendo todos os Ministérios responsáveis por programas sociais do governo federal, a Casa Civil da Presidência da República e a CEF para "articular, orientar e dar apoio técnico aos municípios" que participavam desses programas, no processo de implantação do Cadastro Único. (BRASIL, 2001a) O Grupo era coordenado pela SEAS, do MPAS, mas a comunicação com o Ministério era muito vaga, e os municípios não conseguiam acompanhar as mudanças que eram sugeridas.

[...] a gente fazia ao mesmo tempo o papel do agente operador, pra tocar o sistema, para as coisas acontecerem, e a gente fazia ao mesmo tempo o papel de meio de campo, porque ainda não existia site do $\mathrm{MDS}^{36}$, os municípios não ficavam sabendo das coisas, as coisas aconteciam, um decreto era publicado. [...] eles só sabiam dois meses, três meses depois. (Ent. 2)

Segundo a entrevistada, no intuito de diagnosticar as dificuldades enfrentadas pelos municípios, a CEF realizou uma pesquisa através de suas agências no território baiano, buscando identificar os problemas enfrenta-

36 O Ministério do Desenvolvimento Social e Combate à Fome (MDS) foi criado em 2004 e centralizou basicamente as ações concernentes à segurança alimentar, assistência social e transferência de renda do governo federal. (BRASIL, 2003d) 
dos junto ao Cadastro Único. O relatório gerado a partir desse trabalho tornou-se uma referência para a atuação da Caixa $^{37}$ e consequentemente para a melhoria do processo de implementação do Cadastro. Contudo, as mudanças significativas parecem ter ocorrido mesmo a partir de intervenções mais precisas do governo federal sobre os fatores geradores dos problemas.

[...] não era possivel mais as secretarias trabalharem daquela forma segmentada como estavam trabalhando, até porque, [...] essa própria forma de trabalho da secretaria terminava acarretando duplicidade de cadastro, porque tinha uma família cadastrada com um determinado nome, um determinado documento e a outra secretaria, por um lapso ela omite um sobrenome ou digita uma data de nascimento errada, [...] pro cadastro poderiam ser duas pessoas, então ele gerava duas informações diferentes, como se fossem duas pessoas diferentes, mas na verdade era um cadastro só. (Ent. 2)

$\mathrm{Na}$ entrevista, a definição do tipo de documento exigido do responsável legal da família é apontada como principal medida na redução das duplicidades de registro. Inicialmente, o responsável era o único a apresentar documentos para se cadastrar e podia apresentar qualquer documento; posteriormente, deu-se a definição por um documento de abrangência nacional e de algum documento para todos os membros da família. Outra medida destacada foi a criação do Índice de Gestão Descentralizada (IGD), que teria propiciado o aparelhamento da administração municipal para a operação do Cadastro. O IGD foi criado ao final de abril de 2006 (BRASIL, 2006c) para disciplinar as "ações de apoio financeiro" aos municípios aderentes ao Bolsa Família e ao CadÚnico.

Esses e outros aspectos que se referem às mudanças mais recentes sobre a execução do Cadastro Único serão tratados mais à frente. Aqui interessa recompor as circunstâncias em que se deu a implantação desse novo cadastro para a implementação de programas de transferência de renda. Considerando a operação dos diferentes programas vinculados a diferentes setores da administração pública, cada um deles dispondo de uma dinâmi-

37 Talvez esse Relatório oferecesse dados ainda mais consistentes para a reconstrução do processo que pretendemos, mas infelizmente ele se perdeu na CEF. A nossa entrevistada tentou encontrá-lo tanto no momento da entrevista quanto depois, em contatos que mantivemos, mas sem sucesso. 
ca própria de identificação e seleção de seus beneficiários, verifica-se que desde a sua concepção o cadastro unificado tendia a oferecer dificuldades às administrações municipais que, na ponta, foram responsabilizadas pelo cadastramento. É verdade que na Bahia os municípios contaram com o apoio do governo estadual, isso decerto amenizou, mas não sanou as dificuldades, principalmente porque esse apoio se deu especificamente em razão do PETI, fato que possivelmente contribuiu para a manutenção da separação entre as áreas. $\mathrm{O}$ cadastramento em separado, aliado às dificuldades no uso das novas ferramentas, funcionou à revelia da regra de unicidade pretendida com o novo cadastro, fato que fica mais evidente ao estender-se a análise ao território nacional, quando se constata uma ausência, ou uma presença bastante tangencial, do governo federal no cumprimento da tarefa de orientar os municípios no processo de implantação do Cadastro Único.

\section{DIVERGÊNCIAS ENTRE AS METAS DE CADASTRAMENTO DE BENEFICIÁRIOS E A CAPACIDADE OPERACIONAL DOS MUNICÍPIOS NA EXECUÇÃO DO CADASTRO}

Este tópico toma por referência o debate realizado no âmbito do CNAS, órgão federal deliberativo, instituído pela LOAS, de composição paritária entre governo e sociedade civil. (BRASIL, 1993, Art. 17ss) Em julho de 2002, o CNAS, em reunião ordinária, ${ }^{38}$ incluiu em sua pauta um painel para discussão sobre o Cadastro Único e sobre os Programas Bolsa Escola, Bolsa Alimentação e Auxílio Gás, com exposição de representantes dos órgãos gestores de cada programa e do Cadastro.

Ao apresentar o Cadastro Único, a representante da SEAS, Sra. Ellen Sampaio, afirmou que todos os 5.561 municípios brasileiros já haviam recebido os formulários para o cadastramento, totalizando 13 milhões de cópias distribuídas, com um retorno de 2,4 milhões de famílias já cadastradas. A expositora afirma que, embora haja dificuldades, o processo de cadastramento transcorre normalmente e dentro das expectativas em todos os mu-

38 Trata-se da $92^{\mathrm{a}}$ Reunião Ordinária do CNAS, ocorrida entre 16 e 17 de julho de 2002. A ata disponível na internet (http://www.mds.gov.br/cnas/reunioes-do-cnas/reunioes-ordinarias /atas/atas-de-2002/atas-de-2002) traz o timbre do Conselho Nacional de Previdência Social, mas o conteúdo atesta, desde o início, que se trata do CNAS. Decerto houve erro na digitação. 
nicípios, dos quais mais de 50\% (3.123 dos 5.561 municípios, o que perfaz $56 \%$ precisamente) já haviam registrado algum dado na base do cadastro. Contudo, a "expectativa” apresentada era de que, até o final daquele ano, cerca de 9,3 milhões de famílias, ou o total estimado de famílias pobres (aquelas com renda per capta inferior a meio salário mínimo ou $\mathrm{R} \$ 100,00$, em 2002), estivessem cadastradas, o que significava dizer que deveria haver, entre julho e dezembro de 2002, o cadastramento de mais 6,9 milhões de famílias, um aumento de aproximadamente $290 \%$ em relação ao número de registros já efetuados desde a implantação do Cadastro, havia dez meses.

A expositora ressalta que o Cadastro Único foi criado para "simplificar a relação dos municípios com todos os programas federais de distribuição direta de renda" e para oferecer às três esferas da administração pública "um diagnóstico da situação social do país”. (BRASIL, 2002h, p. 116) O cadastro é, então, uma ferramenta para planejamento de ações e programas mais condizentes com a realidade; além disso, ofereceria ganhos no que tange à redução de custos, pois um único cadastro atenderia aos mais diversos programas, inclusive àqueles de caráter emergencial, concebidos em razão de secas e enchentes. "Essas famílias mais vulneráveis, já estando cadastradas e de posse do seu cartão, poderão receber o pagamento de qualquer auxílio adicional que o governo queira disponibilizar para elas praticamente a partir do comando nesse sentido". (BRASIL, 2002h, p. 116) Até aquele momento, já havia três programas utilizando o Cadastro: Bolsa Escola, Bolsa Alimentação e Auxílio Gás, com previsão de que até o mês de setembro também o PETI e o Agente Jovem ${ }^{39}$ o fizessem, e, assim, todos os benefícios estariam condicionados à inscrição no Cadastro Único.

É importante mostrar para o gestor municipal que quando ele tiver acesso à relação de beneficiários constantes do Cadastro Único terá a identificação precisa e correta das famílias mais vulneráveis do seu município e poderá atendê-las a qualquer momento, a partir das informações já coletadas, cadastradas e processadas (BRASIL, 2002h, p. 117)

Ainda com relação à redução de gastos, observa-se que "todos os custos de operação do Cadastramento Único são divididos entre o Ministério da Saúde, o Ministério da Educação, o Ministério de Minas e Energia e o

39 O Projeto Agente Jovem de Desenvolvimento Social e Humano, regulado pela Portaria SEAS $n^{\circ} 879$, de dezembro de 2001, não é objeto de análise no presente trabalho. 
Ministério de Desenvolvimento Agrário [e a] SEAS”. (BRASIL, 2002h, p. 117) Segundo cálculos da expositora, cada órgão paga o equivalente a um quinto do que pagaria num cadastro isoladamente.

O cadastramento único teria também a utilidade de ser realizado em equivalência ao cadastro do Sistema Único de Saúde (SUS), substituindo-o. Citando uma convocação feita pelo Ministério Público Federal (MPF) à SEAS para prestação de explicação sobre a necessidade do Cadastro Único, em face da existência já de um cadastro daquela natureza, o Sistema de Cadastramento de usuários do SUS (CadSUS), a expositora indica que o MPF compreendeu que o cadastro do SUS visa atender à totalidade da população brasileira, enquanto que o Cadastro Único pretende alcançar um foco: é um cadastro exclusivo para "as famílias que estão abaixo da linha de pobreza". (BRASIL, 2002h, p. 118) Seu conteúdo atende, portanto, aos requisitos do CadSUS e vai além, sendo muito mais completo, pois em sua formulação teriam sido considerados os conteúdos dos cadastros dos programas de transferência de renda e o próprio cadastro do SUS: "Nós juntamos esses programas e colocamos todas as informações indispensáveis a eles neste novo formulário, que passou a conter as informações necessárias à operação de todos os programas”. (BRASIL, 2002h, p. 119) Em conta disso, foi superada a exigibilidade para os municípios realizarem o CadSUS, estando este já contemplado no Cadastro Único.

Isso fez muita diferença para municípios pequenos, que às vezes tinham dificuldades de operar os dois cadastros ao mesmo tempo. A partir dessa decisão, eles souberam que cadastrando as famílias de baixa renda no Cadastro Único estariam completando a sua meta de cadastramento do SUS, e, portanto, receberiam do Ministério da Saúde o equivalente ao que receberiam se tivessem feito o cadastramento diretamente pelo SUS.

Por que isso? Porque toda a informação contida no formulário de Cadastramento do Sistema Único de Saúde está contida no formulário do Cadastramento Único. O formulário de Cadastramento Único contém essas e todas as informações necessárias à operação de todos o programas sociais. (BRASIL, 2002h, p. 118)

Esse dado traz elementos importantes à análise, pois pela primeira vez aparece a possibilidade de alguma remuneração ao município pela realização do cadastro. Note-se que essa remuneração é remanejada, não se refere diretamente ao Cadastro Único. Faz-se o que talvez se possa chamar de um 
arranjo operacional para desafogar o município da sobrecarga de cadastramento, mas também há que se observar que esse fato se deu pela intervenção de um ator externo, o MPF, e o que se alterou em verdade foi a política de cadastramento do SUS, não dos programas sociais. Também aqui são fornecidos elementos para compreender a relação do programa Bolsa Alimentação com o Cadastro Único, pois, como se viu, o seu cadastro era de responsabilidade do setor de informática do SUS, não da Caixa Econômica, como o Bolsa Escola, ou da SEAS, como ocorreu inicialmente com o PETI. Assim, ainda que processado pelo DATASUS, o cadastro do programa teria a mesma origem dos demais. Ainda não se consegue alcançar, porém, o processo que permitiu a migração dos dados entre as duas bases, como se percebe nas exposições que seguem.

O representante do Ministério da Saúde, Eduardo Filizzola, expôs brevemente as características do Programa Bolsa Alimentação, ${ }^{40}$ indicando que o recurso transferido pelo programa, com previsão "da ordem de 572 milhões de reais", "deve ser gasto de maneira adequada para a aquisição de alimentos necessários ao combate da desnutrição das crianças”. (BRASIL, 2002h, p. 128) O programa tem por perspectiva atender a 3,5 milhões de pessoas, estando presente, até aquele momento, em cerca de dois mil municípios, atendendo a cerca de 500 mil pessoas, cobertura esta que deveria duplicar até o mês seguinte àquela exposição. Destaca-se também a influência positiva da utilização desses recursos "na atividade comercial dos municípios”. (BRASIL, 2002h, p. 128) Observe-se que nesse primeiro momento não há alusão do expositor ao processo de cadastramento dos beneficiários do programa, ainda que apresente os seus critérios de elegibilidade: gestantes, nutrizes e crianças entre seis meses e seis anos e onze meses de idade, em risco nutricional e numa faixa de renda per capta familiar de até meio salário mínimo. Este último, critério condizente com o estipulado para o Cadastro Único.

Do Bolsa Escola, expôs-se que em seus 18 meses de existência o programa já alcançava a quase totalidade dos municípios brasileiros (dos 5.561 municípios apenas 25 não teriam feito a adesão), com “100\% dos recursos

40 Na ordem de exposição, o Bolsa Alimentação aparece por último, precedido pelo Bolsa Escola e pelo Auxílio Gás, não obedecendo, portanto, à cronologia de implementação dos programas. Aqui também desconsideramos tal cronologia, uma vez que não influencia no que ora está em análise, optando por discutir primeiro a exposição sobre o Bolsa Alimentação, a fim de manter a coerência textual. 
oriundos do Governo Federal" (BRASIL, 2002h, p. 128, p. 120), um orçamento anual de aproximadamente 2 bilhões de reais, transferidos diretamente às cerca de 5,5 milhões de famílias cadastradas. Aqui se ressalta o papel desempenhado pelos municípios nesse processo:

A prefeitura é o grande gestor do programa Bolsa-Escola, atuando na ponta. Ela deve efetuar o cadastramento dos beneficiários, o que, num primeiro momento, foi feito sob a ótica desse programa e agora tem sido feito por intermédio do Cadastramento Único. (BRASIL, 2002h, p. 128, p. 121)

Destaca-se ainda a obrigatoriedade das prefeituras municipais em criar programas socioeducativos, investir na educação pública e acompanhar a condicionalidade do programa, de frequência escolar mínima de $85 \%$ para os seus beneficiários, além da criação ou delegação de um conselho de controle social. A meta de cobertura do programa era de 5,6 milhões de famílias até o final daquele ano. (BRASIL, 2002h, p. 123)

O Auxílio Gás, próximo programa da exposição, não foi apresentado acima, na seção que trata do contexto de criação do Cadastro Único, ${ }^{41}$ porque ele é posterior à instituição do Cadastro, mas já nasce, como se verá, fazendo uso dele. A criação do Programa foi autorizada em dezembro de 2001, através da Medida Provisória n. ${ }^{\circ}$ 18, que dispunha sobre “subvenções ao preço e ao transporte do álcool combustível e subsídios ao preço do gás liquefeito de petróleo - GLP” (BRASIL, 2001g), porém, a sua criação de fato se deu já ao final de janeiro de 2002, através do Decreto n. ${ }^{\circ}$ 4.102/2002, que o regulamentou. Definiu-se, então, como público alvo do programa, as famílias de baixa renda (BRASIL, 2002b, Art. $1^{\circ}$ ), consideradas nessa condição aquelas com renda per capta mensal de até meio salário mínimo, registradas no Cadastro Único ou beneficiárias, efetivas ou potenciais, dos programas Bolsa Escola ou Bolsa Alimentação. (BRASIL, 2002b, Art. $3^{\circ}$ ) O valor do benefício foi fixado em $R \$ 7,50$, pago cumulativamente $(R \$ 15,00)$ a cada dois meses. (BRASIL, 2002b, Art. $4^{\circ}$ )

Ao expor sobre esse programa, Ricardo Dornelles, do Ministério de Minas e Energia (MME), indica que ele difere, em alguns aspectos, dos demais programas de transferência direta de renda, pois a sua criação corres-

41 Abordado no capítulo "Focalização sem foco: fragmentação dos primeiros programas sociais de transferência de renda focalizados". 
ponde a uma determinação legal decorrente da flexibilização do monopólio do petróleo no Brasil.

Quando se flexibilizou o monopólio do petróleo, a lei que executou essa abertura determinou que, ao final do período de transição, todos os subsídios a derivados de petróleo existentes no país acabassem ou fossem substituídos por novos subsídios. (BRASIL 2002h, p. 123)

Afirma-se que já havia um subsídio do Estado ao "gás de cozinha", o GLP, mas que era transferido diretamente à Petrobras. Com a extinção desse subsídio à refinaria, o Programa veio compensar a elevação do preço do produto para as famílias de baixa renda. A vinculação do Auxílio Gás ao Cadastro Único e aos outros programas teria se dado em função da necessidade de alcançar rapidamente o seu público-alvo, no intuito de compensar os reajustes sofridos pelo gás de cozinha no mês de janeiro (2002).

É importante lembrar que, anterior a isso, havia uma determinação da própria legislação do Cadastro (Decreto n. ${ }^{\circ} 3.877 / 2001$ ) que impunha a sua utilização para programas dessa natureza, o que obviamente não podia ser ignorado. Mas o Cadastro estava ainda sendo implantado, com todas as dificuldades e limitações desse processo; assim, é a vinculação aos programas já operantes que facilitará a implantação do Auxílio. A meta de cobertura do programa eram as 9,3 milhões de famílias de baixa renda em todo o país, segundo a estimativa do governo federal, das quais atingira quase $60 \%$ já em sua primeira folha de pagamentos.

No primeiro mês em que foi pago, o programa já beneficiou 5 milhões e 488 mil famílias, que eram basicamente aquelas beneficiárias do Bolsa -Escola no mês de janeiro, mais cerca de 22 mil famílias beneficiárias do Bolsa-Alimentação, que não eram atendidas pelo Bolsa-Escola. (BRASIL, 2002h, p. 125)

Dornelles reconhece que milhares de famílias estavam aptas ao recebimento do novo benefício desde a sua implantação, e, à medida que o Cadastro Único avançava, o número de beneficiários potenciais aumentava, mas essas famílias não podiam ser atendidas porque não estavam inclusas nos outros programas. Uma vez que os benefícios eram sacados diretamente, a ausência de uma conta para o seu repasse e consequentemente de um cartão magnético para o saque criou essa dificuldade. Esse problema foi resolvido a partir de junho, quando o governo federal lançou o "cartão do cidadão", 
cuja finalidade era atender a todos os programas de transferência de renda. Um cartão único, por assim dizer.

Mas as dificuldades iam além dessa inadequação entre os programas ou entre os procedimentos para concessão de seus benefícios. O debate desenvolvido pelos Conselheiros do CNAS demonstrou que os municípios enfrentavam uma carga de problemas outros, a começar pela responsabilidade que lhes era imposta de realizar o cadastramento. "O que está previsto pelo Governo Federal para auxiliar os municípios de pequeno porte [...], a fim de que possam operar o Cadastro Único?”. (BRASIL, 2002h, p. 131) 42 $^{42}$ De acordo com o que se depôs, em muitos casos o cadastramento representou uma espécie de engessamento da área de assistência social e da capacidade operacional das administrações municipais porque demandava tempo e pessoal, recursos escassos nos municípios.

A efetivação de cada cadastro por assistentes sociais nos municípios está levando de 50 a 60 minutos. Para cadastrar uma população de 900 famílias seriam necessárias 750 horas de trabalho de um assistente social. Nos municípios de pequeno porte não há assistente social, ou há apenas um assistente social, ao qual é cometida a responsabilidade de fazer o Cadastro Único. (BRASIL, 2002h, p. 131)

A essa questão, a representante da SEAS responde referindo-se à "compensação" gerada na equivalência estabelecida entre o Cadastro Único e o CadSUS: "nós pensamos que aquela seria a solução do problema dos municípios de pequeno porte. Isso tem se revelado no volume de adesões de novos cadastramentos que temos recebido a partir de então". (BRASIL- 2002h, p. 135) Essa elevação no cadastramento, porém, pode estar indicando que havia de fato uma sobrecarga de trabalho. É possível supor que as equipes que realizavam o cadastramento nos domicílios, quando era o caso, tinham que fazê-lo duplamente, o que teria se revertido com a equivalência dos cadastros. Caso isso seja verdadeiro, não foi o valor repassado aos municípios ( $\mathrm{R}$ \$ o,9o centavos por cadastro) que teve importância principal - porque era insufi-

42 Considerando que o nome dos conselheiros não tem influência para os fins deste trabalho, optamos por não expô-los. De todo modo, o documento no qual constam é de livre acesso a quem possa interessar. 
ciente para contratar equipes de cadastradores, e seu repasse era posterior ao cadastramento -, mas a redução da carga de trabalho que lhes era imposta. ${ }^{43}$

Uma queixa igualmente importante de conselheiros do CNAS era quanto à falta de acesso à base de dados. Apesar de o cadastramento ser realizado no município, e do objetivo propalado de auxiliar na formulação de políticas localmente, os dados processados não retornavam, pelo que a administração municipal não podia ter qualquer controle em relação ao quantitativo efetivamente cadastrado.

[...] nós simplesmente formulamos [sic] o cadastro e não temos acesso ao retorno das informações. Não podemos, portanto, operar o programa no âmbito do nosso município, porque não temos acesso à base de dados e não podemos saber quem entrou no cadastro, quem não entrou, como se fazem trocas de informações, como se gerencia isto ou aquilo. (BRASIL, 2002h, p. 132)

Segundo o representante do MEC, Sr. Romeu Luizatto, as informações sobre o programa Bolsa Escola já estariam disponibilizadas, mas, ao que se percebe, tratam-se de informações bastante recortadas, com o fito exclusivo de garantir o acompanhamento da frequência escolar exigida pelo programa: "todos os municípios estão recebendo agora e vão receber a cada três meses um CD com a informação de todos os alunos beneficiários, divididos por escola, com todas as informações sobre os trimestres anteriores". (BRASIL, 2002h, p. 146) Continuando, o gestor faz alusão a discussões do Grupo de Trabalho do Cadastro Único ${ }^{44}$ indicando que a indisponibilidade da base do Cadastro Único deve-se ao fato de ela estar ainda incompleta. A Sra. Ellen Sampaio (SEAS), por sua vez, afirma que já há alguma disponibilidade de dados no "arquivo-retorno" que é remetido pela CEF aos municípios, porém, o conteúdo desse arquivo é bastante limitado porque

43 Contudo, esse argumento não pode ser igualmente utilizado para se pensar na digitação dos dados, uma vez que não está claro quem os transmitia ao DATASUS, se a Caixa Econômica ou o município, caso em que a dinâmica de trabalho seria mantida. E esse é um questionamento que se reforça ao se considerar que o cadastro do SUS era para toda a população e, por isso, na hipótese de que se atingisse a meta do Cadastro Único, haveria que se continuar cadastrando para o SUS.

44 Trata-se do GT instituído pelo Decreto de 24 de outubro de 2001 , definindo a forma de articulação dos órgãos federais com os municípios, para fins de viabilização do processo de cadastramento, como se viu anteriormente. 
a liberação dos dados substanciais necessita de regulamentação legal, o que estaria ainda em processo.

[...] essa base ainda não está disponível para os municípios porque nós dependemos de uma legislação sobre os critérios de sua utilização, que tem que ser aprovada pelo Congresso Nacional.

Hoje o município recebe um arquivo-retorno, como o chamamos. Depois que o município transmite todos os dados, eles voltam, processados, apenas com o nome do responsável e o dos membros da família e o número de identificação social que foi atribuído para cada um. Só isso está disponível hoje. (BRASIL, 2002h, p. 153)

Queixa-se de que há problemas também de comunicação, com dificuldades de acesso à informação ou informações desencontradas, o que se atribui à dispersão dos programas, pela inexistência de uma coordenação comum aos mesmos: "No dia da divulgação do Auxílio-Gás, formaram-se filas imensas na frente das prefeituras municipais, e não havia ninguém neste país para nos dar informações sobre esse bendito programa. Foi um horror”. (BRASIL, 2002h p. 149) Essa necessidade de aproximação das ações sociais é reconhecida pela própria equipe do Governo, o que em sua interpretação já estaria em curso, demonstrado na relação entre um cadastro e um cartão únicos, dois polos de uma articulação ampla entre os programas sociais.

Em junho foi lançado o cartão único [Cartão do Cidadão]. Temos um Cadastramento Único, que é o início da operação, e temos um cartão único, que é o final da operação. Entre o início e o final, trabalhamos com as divisões e as características de cada um dos programas sociais. (BRASIL, 2002h, p. 17o)

Tratando ainda das dificuldades na linha do financiamento, e referindo-se à afirmação anterior do gestor do Bolsa Escola, de que os recursos do programa eram oriundos integralmente da União, uma das conselheiras pergunta: "o senhor tem noção de quanto gastam os municípios para viabilizar o que está determinado no Bolsa-Escola?”. (BRASIL, 2002h p. 149) E mais à frente a mesma conselheira oferece um exemplo que ilustra mais francamente as dificuldades municipais, considerando as especificidades de cada região, quando as condições naturais desafiam a limitada logística de que se dispõe. 
Há um mês, por exemplo, contei para a Dra. Ellen e para a Conselheira Roberta que eu estive em Roraima, e a preocupação do prefeito de uma cidade daquela região era o fato de que ele demorava 21 dias para ir de barco ao alto do Rio Branco, cadastrar as 700 famílias que vivem lá e voltar. Ele não tinha dinheiro para combustível, não tinha uma voadeira. Eu até sugeri a ele que mandasse um projeto de financiamento para algum ministério. Disse-lhe: 'Quem sabe eles financiam para vocês, porque realmente esta situação é concreta'. As nossas regionalidades têm que ser entendidas. (BRASIL, 2002h, p. 149)

E os problemas não param por aí. A falta de critérios ou meios específicos para atualização de informações do Cadastro também foi um ponto levantado, e, nesse sentido, a queixa remete-se diretamente ao agente operador do Cadastro Único:

[...] os senhores contrataram um sistema feito pela Caixa Econômica Federal, que é banco e só sabe fazer cadastro de banco. Mas nós precisamos ter um cadastro social, que retorne ao município, que possa ser trabalhado e cujas alterações possam ser medidas. (BRASIL, 2002h, p. 150)

Em resposta, justifica-se a escolha pela Caixa em razão do pagamento direto às famílias, o que demandaria serviços de um agente financeiro, e quando do convite para apresentação de propostas nesse sentido, apenas esse banco teria se apresentado. (BRASIL, 2002h) Junto a isso, são discutidas algumas das utilidades e características do cadastro, pelo que não se constituiria apenas em um "cadastro de banco", como sugerido. Exemplo disso estaria na possibilidade de mapeamento das pessoas que não têm documentação civil que, embora não se possa inseri-las nos programas, oferece condições para resolver o problema. (BRASIL, 2002h)

Os conselheiros queixam-se também da exclusão do CNAS na formulação dos programas sociais, que seriam apresentados ao Conselho unicamente para se dar conhecimento, após serem criados (BRASIL, 2002h): “Às vezes, temos a sensação de que o Conselho é um ser etéreo, porque tomamos conhecimento dos programas depois que eles já foram criados e só então fazemos a discussão". (BRASIL, 2002h, p. 158) Nesse sentido, sugere-se a inclusão dos conselhos nacionais quando da formulação da regulamentação para o uso da base de dados do Cadastro.

Minha pergunta é: quem vai regulamentar? Como está o processo que está sendo encaminhado? Meu pedido é que nesse processo de regulamentação da base de dados os Conselhos Nacionais estejam presentes. 
Nós precisamos ter muito claro que essa será uma fonte de informação fundamental em todas as instâncias, a informação é necessária e estados e municípios e Conselho Nacional precisam fazer uma discussão conjunta. Sobre um ponto é um pedido, a outra é uma pergunta: em que estágio se encontra essa regulamentação? (BRASIL, 2002h, p. 163)

O que se consegue perceber é que as dificuldades e os problemas enfrentados pelos municípios para a implantação do Cadastro Único eram de conhecimento do governo federal, e algumas medidas eram adotadas para tentar revertê-los. Mas essas medidas eram insuficientes e não alcançavam a demanda apresentada, principalmente porque a fonte dos problemas era diversa, dada a operação de diferentes programas e a inexistência de uma articulação eficiente dos seus órgãos gestores. De outro lado, o estabelecimento de metas de cadastramento parece ignorar a existência dos problemas, pretendendo-se, em um curto intervalo de tempo, quase que quadruplicar o número de registros efetuados, alcançando a totalidade da estimativa sobre o público-alvo. A ausência de recursos das mais diversas ordens mostrará, porém, a inexequibilidade desse intuito e fará com que as dificuldades se acentuem, comprometendo a qualidade do cadastro e exigindo do governo a adoção de medidas mais precisas e eficientes no enfrentamento das limitações, e, como no caso da equivalência entre o Cadastro Único e o CadSUS, um ator externo desempenhará papel importante nesse processo: o TCU.

\section{FRAGILIDADES DO CADASTRO E INCONSISTÊNCIAS NAS INFORMAÇÕES PARA IDENTIFICAÇÃO DA POPULAÇÃO POBRE}

Ao final de 2002, o TCU realizou uma auditoria específica sobre o Cadastro Único, cujos resultados foram divulgados em 2003, para verificar o grau de consistência dos seus registros e a influência que esse cadastro exercia sobre os programas que o utilizavam e sobre o acesso das famílias aos benefícios desses programas. Um dos objetivos postos para a auditoria era contribuir para melhorar tanto a qualidade quanto a cobertura alcançadas pelo Cadastro Único, ou seja, melhorar o grau de focalização desse cadastro. O Tribunal realizou estudos de caso, com aplicação de entrevistas estruturadas a gestores e beneficiários dos programas, numa amostra de 32 municípios, selecionados em função do número de cadastros já realizados até então, da razão entre quantidade de famílias carentes e de pontos de 
atendimento da CEF e da localização geográfica de cada município em relação à capital do estado ao qual pertencia. Além disso, realizou-se pesquisa postal direcionada a 648 outros municípios, obtendo um retorno de pouco mais de 51\%. (BRASIL, 2003m) De posse desses dados, o TCU procedeu à análise.

Considerando a característica de unicidade do Cadastro Único, prevista no decreto de sua criação, e que constitui uma das características fundamentais do mesmo (BRASIL, 2001e, Art. $2^{\circ}$ ), a auditoria verificou que o software desenvolvido pela Caixa Econômica para absorção dos dados cadastrais continha brechas que permitiam a duplicidade de registros. A unicidade estava, assim, comprometida, porque um mesmo beneficiário podia ser registrado com mais de um NIS, possibilitando (inclusive) o pagamento indevido de benefícios, fato que também comprometeria a possibilidade de mapeamento do público-alvo da Assistência Social, não fornecendo informações confiáveis quanto à sua dimensão. Testando esse aspecto, os auditores do TCU analisaram a situação do Rio Grande do Norte, RN, com dados de setembro de 2002, e constataram a existência de mais de 4,8 mil casos de NIS excedentes, inclusive com pessoas contendo mais de dois registros. (BRASIL, 2003m, p. 15) ${ }^{45}$ Mas, além da falha no aplicativo, indica-se que esse problema deveu-se, também, à ação descoordenada de diferentes grupos de cadastradores, relacionados às áreas específicas de cada programa, e de suas estratégias de cadastramento, que permitiam a apresentação de documentos diferentes por um mesmo indivíduo para cada novo registro.

O Relatório do TCU indica que até setembro de 2002, segundo a amostra da pesquisa, as duplicidades já atingiam mais de 458 mil casos, o que representava $2,7 \%$ do total de registros realizados. O Tribunal observa que há uma cláusula no Contrato da CEF com o Ministério responsável pela coordenação do Cadastro, o Ministério da Assistência e Promoção Social

45 O Rio Grande do Norte era o estado que apresentava maior número de registros no Cadastro Único, alcançando $92,5 \%$ da meta estipulada, uma realidade positivamente contrastante da maioria absoluta dos demais estados e do Distrito Federal, este, à época, sem qualquer registro realizado. (BRASIL, 2003m, p. 26) 
(MAPS), ${ }^{46}$ que prevê a depuração interna dos dados. Assim, visando corrigir os problemas de verificação de unicidade, o Relatório de Auditoria sugere ao Ministério que solicite à CEF a realização desse processo. Mas há casos também de duplicidade de cadastros com o mesmo NIS, revelando outra falha ou limitação do aplicativo, porque não oferecia mecanismos de manutenção do cadastro, com atualização dos dados, e por isso, ao registrarem-se novas informações sobre uma mesma pessoa, gerava-se um novo registro.

Os formulários do Cadastro têm um "código domiciliar" previamente impresso, o que, a princípio, deveria evitar a repetição desses registros especificamente; porém, o problema da falta de formulários, que leva alguns municípios a se utilizarem de fotocópias, aliado às dificuldades no processo de envio eletrônico dos dados, provoca um novo erro, a repetição dos códigos domiciliares, cuja ocorrência, à época da Auditoria, supera os 77,4 mil casos. O Relatório aponta para a possibilidade de prejuízo na atenção aos beneficiários, decorrente das multiplicidades do Cadastro, isto porque o cadastramento se dá em função das estimativas de pobreza fornecidas aos municípios, e a repetição de dados pode gerar a ilusão de alcance das metas definidas, sem de fato isso ter ocorrido. Solicita-se assim que se desenvolvam mecanismos de bloqueio das repetições desde o processamento dos dados. (BRASIL, 2003m, p. 17)

A multiplicidade de cadastramento provoca o armazenamento de informações conflitantes sobre uma mesma pessoa/família, trazendo obstáculos para a identificação de pessoas pobres. Além do mais, as estatísticas sobre a evolução do Cadastro Único ficam superestimadas, pois as multiplicidades não são excluídas do cômputo de pessoas, famílias $e$ domicílios. Se for utilizada a estimativa de famílias pobres como meta para finalização ou redução da prioridade dada ao Cadastro Único, muitas famílias podem ser deixadas de fora por conta desses sobre cadastramentos. (BRASIL, 2003m, p. 19, grifo nosso)

Essas observações remetem às limitações do processo de digitalização dos dados e apontam, portanto, para as dificuldades no instrumento desen-

46 "À época da realização da auditoria, as ações de cadastramento eram coordenadas pela Secretaria de Estado de Assistência Social - SEAS, vinculada ao Ministério de Previdência e Assistência Social - MPAS. Com a edição da Medida Provisória n. ${ }^{\circ}$ 103, de 01.01.03, a SEAS foi transformada no Ministério da Assistência e Promoção Social - MAPS (Art. 31, VII), enquanto o MPAS foi transformado no Ministério da Previdência Social (Art. 31, IX)”.' (BRASIL, 2003m, p.3) 
volvido para a geração de informações sobre a população pobre. Pode-se inferir, então, que o software de entrada de dados pautava-se em procedimentos meramente aditivos, sem crítica quanto à origem desses dados, o que comprometia o intuito maior de eficácia na identificação e no cômputo de todas as famílias pobres, tornando o dimensionamento de seu contingente com limites pouco precisos, o que, por sua vez, de certa forma, comprometeria o foco dos programas. Outros problemas de focalização foram identificados, como a subdeclaração da renda no momento do cadastramento, que se reflete na seleção do público-alvo dos programas. Retomando o caso do $\mathrm{RN}$, a equipe de auditoria cruzou os dados referentes ao NIS com aqueles do Número de Identificação do Trabalhador (NIT), constantes na base do Sistema de Benefícios do INSS, o Sistema Único de Informações de Benefícios (SISBEN). O resultado apontou para a existência de centenas de situações que sugeriam a existência de subdeclaração no Cadastro Único em pelo menos $\mathrm{R}$ \$ 20,oo, incluindo centenas de outros casos em que a subdeclaração superava um salário mínimo, que à época estava em $\mathrm{R} \$ 200,00$, fato que possibilitava a inclusão no Cadastro de pessoas com renda acima da linha do corte dos programas sociais e, consequentemente, o recebimento indevido de benefícios. Uma outra forma de cruzamento proposta ao governo através do Relatório é com a Relação Anual de Informações Sociais (RAIS), do Ministério do Trabalho e Emprego (MTE), como fonte para a verificar a correspondência entre a renda declarada no Cadastro Único e a constante daquela base de dados.

Embora esse fato aponte para uma lacuna importante no processamento do Cadastro Único, há que se ponderar que o critério utilizado pelo TCU não é suficiente para mensurar as suas consequências, porque não alcança outras características das famílias identificadas em tal condição. Isso porque o Cadastro utiliza-se da renda familiar per capta, e não a individual, assim, ainda que a renda do titular do benefício seja superior à declarada, não necessariamente a família estará fora do perfil dos programas em questão. Além disso, o próprio TCU reconhece inconsistências nas próprias bases de dados tomadas como referência. (BRASIL, 2003m) De todo modo, a identificação desse problema será de elevada importância para o aprimoramento do Cadastro futuramente.

No Relatório, ressalta-se que a utilidade do cadastro está relacionada à qualidade dos seus dados (BRASIL, 2003m), e, nesse sentido, chama-se a atenção também para a ausência de mecanismos de alteração cadastral, 
problema apontado como sendo decorrente de uma opção inicial do Governo em alimentar rapidamente o banco de dados. Isso porque havia uma orientação da SEAS para a totalização do Cadastro até outubro de 2002, de modo a permitir a concessão dos benefícios ainda naquele ano. ${ }^{47}$ Verificouse que a falta desses mecanismos, aliada à orientação deficiente, fez com que muitos municípios acionassem com frequência os Ministérios responsáveis por cada programa, no intuito de realizar alterações no Cadastro, demandas que, em diversos casos, não obtiveram respostas.

O Tribunal indica ainda que, àquela época, a CEF já estava desenvolvendo uma "rotina de alteração cadastral" (BRASIL, 2003m, p. 23), mas observa que a atualização dos dados pelos municípios demandariam recursos dos quais eles não dispunham. Assim, o TCU recomenda "que o MAPS estude a possibilidade de haver repasse aos municípios de recursos para manutenção/atualização permanente dos dados inseridos no Cadastro Único". (BRASIL, 2003m, p. 24) Com o mesmo fim, o Tribunal sugere também que a atualização seja precedida de programa de capacitação dos operadores do cadastro nos municípios (BRASIL, 2003m) e, quando da atualização, que sejam vinculadas mensagens de convocação dos beneficiários através dos seus extratos de benefícios. E, ainda, que os municípios fossem orientados a recorrer aos registros municipais de nascimentos, casamentos e óbitos para verificação da necessidade de atualização. Para o Governo Federal, recomenda-se a utilização do Sistema Informatizado de Controle de Óbitos (SISOBI) com essa finalidade.

Considerando a recomendação de aceleração do cadastramento feita pela SEAS, o TCU testou o estágio em que se encontravam os estados e o Distrito Federal nesse processo e verificou que havia atrasos generalizados. Embora cerca de $89 \%$ dos municípios já tivessem inserido algum dado na base do cadastro, a totalização desses dados alcançava pouco mais de $51 \%$ das famílias estimadas. Junto a isso, havia expressiva heterogeneidade no estágio em que se encontrava cada estado, a exemplo de extremos como Rio Grande do Norte (RN) com 92,5\% e Distrito Federal (DF) com o\%, ou ainda Ceará (CE) com 79,3\% e Rio de Janeiro (RJ) com 12,8\%. (BRASIL, 2003m) E isso em números brutos, sem qualquer depuração, ou seja, se fossem ex-

47 Note-se que 2002 era ano de eleição presidencial, e outubro, o mês de realização do pleito. É possível que esse fato tenha influenciado nessa decisão do Governo pela célere conclusão do cadastramento. Mas não analisaremos esse aspecto no presente trabalho. 
cluídas as duplicidades e inconsistências, as discrepâncias poderiam ainda se acentuar. Diante dos números aferidos, o TCU estimou que apenas cinco estados concluiriam a tarefa ainda em 2002, 17 deles durante 2003 e outros três apenas em 2004..$^{8} \mathrm{Em}$ conta disso, alerta-se para o risco de prejuízo às famílias carentes beneficiárias dos programas de transferência de renda anteriormente ao Cadastro Único, as quais poderiam sofrer suspensão dos benefícios por não estarem registradas ainda no novo cadastro.

Isso se desdobrou num retorno à análise das causas desse atraso, tendo-se identificado uma série de fatores, ora relacionados a questões operacionais, ora a outras gerenciais. Do ponto de vista operacional, o principal problema apontado foi a "falta de documentação dos beneficiários". (BRASIL, 2003m, p. 28) ${ }^{49}$ As medidas adotadas diante disso pelos municípios variam, destacando-se o preenchimento do formulário sem inserção dos dados na base do Cadastro, até que se proceda a apresentação dos documentos em falta. Segue-se a isso a opção por cadastrar apenas os membros que têm documentos, omitindo-se os demais, ou desconsidera-se sumariamente a família para o cadastramento, dentre outras. Esses dados não depõem apenas em justificativa dos atrasos, mas, sobretudo, contra o princípio censitário do Cadastro Único, e comprometem a cobertura dos programas que utilizam esse Cadastro. Ademais, são também reveladores da deficiência na comunicação e orientação do Governo Federal aos municípios. De todo modo, embora esse problema seja apresentado como um grande entrave ao processo de cadastramento, o TCU reconhece a importância que esse processo exerce indiretamente sobre o que chamou de "resgate da cidadania", pela exigência imposta para realização de campanhas de registros civis, condição para acessar direitos. Observando as várias iniciativas dos estados e municípios para aceleração do processo de expedição de documentação à população alvo dos programas sociais, o Tribunal de Contas recomenda que se adote esse procedimento como prática comum, em favor do público visado pelo Cadastro.

48 A estimativa para 2003 indica textualmente "dezoito" estados, mas na conferência direta do gráfico apresentado verifica-se que são, em verdade, 17, o que condiz com o número de Unidades Federativas do país, considerando que se excluíram dessa estimativa o Rio de Janeiro e o Distrito Federal. Houve, decerto, equívoco na digitação. (BRASIL, 2003m, p. 27)

Nesse caso, beneficiários potenciais, ainda não efetivos. 
As dificuldades na etapa de envio dos dados para a CEF também foram apontadas como um importante fator causador dos atrasos. Esse é um processo relativamente complexo, que demanda conhecimentos e tecnologias específicas. Além da necessidade de um microcomputador que atenda aos requisitos mínimos para instalação e processamento do software, há que se contar com um digitador(a), alguém que não apenas insira os dados, mas que compreenda os procedimentos de "certificação eletrônica" do município junto à Caixa Econômica, de preparação e envio dos dados e de captura do "arquivo retorno", contendo a identificação dos beneficiários. A realização desse processo exige também conexão à internet, o que pode ser substituído pela geração de disquetes de dados entregues e recebidos diretamente numa agência da Caixa. As dificuldades enfrentadas para dar conta do processo se acentuavam com a edição de novas versões do software, indicadas na análise do TCU como incompatíveis em alguns casos (BRASIL, 2003m, p. 31), mas o que está em destaque é, de fato, a deficiência técnica e mesmo financeira dos municípios para dar conta das exigências que lhes eram impostas.

Os problemas referentes à conexão com a Internet e lentidão do sistema não se relacionam, diretamente, aos aplicativos disponibilizados pela CAIXA. São causados pelas deficiências dos equipamentos e sistemas de informática disponíveis nos municípios. Em muitos casos, trata-se de localidades carentes, sem recursos tecnológicos ou com número insuficiente face às atividades demandadas, constatando-se o uso compartilhado de um ou dois computadores para o cadastramento e outros trabalhos das prefeituras, máquinas com defeito ou faltando componentes. Além disso, não há recursos financeiros próprios para aquisição de novos equipamentos e contratação de serviços de digitação, executados via de regra por funcionários das prefeituras com outras atribuições, agravando a sobrecarga dos recursos municipais. (BRASIL, 2003m, p. 31)

Também as dificuldades de acesso às famílias foi posta como causa do atraso na realização do cadastramento, tanto na zona rural ou de ilhas, quanto nas cidades e regiões metropolitanas. Nestes casos, segundo o Relatório, a dificuldade se dá pelos riscos representados na visitação a determinadas áreas, seja pelas características físicas da região, como encostas, seja por aspectos sociais, como os elevados índices de criminalidade, a exemplo das favelas do Rio de Janeiro, pela incidência do crime organizado. Como forma de amenizar tais dificuldades, o TCU reitera a necessidade de repasse financeiro aos municípios para viabilização do cadastramento. 
No que tange ao gerenciamento do processo de cadastramento, o Relatório do TCU afirma que havia uma recomendação da SEAS para que se formassem grupos de trabalho nos municípios para uma ação concertada entre as secretarias executoras dos diferentes programas, mas o que se constatou foi que na maioria dos casos os cadastros se davam isoladamente. A Auditoria atribui esse problema não a divergências políticas ou de qualquer outra natureza interna, mas à “dificuldade de disseminação de informações”, o que não dá aos municípios uma direção correta de como proceder e gera uma série de dúvidas quanto ao processo, além dos problemas com multiplicidades e desperdícios de tempo e recursos.

[...] na maioria dos casos, não houve coordenação entre as secretarias municipais, as quais cadastravam isoladamente o público-alvo dos programas sociais vinculados. Constatou-se que apenas $43,1 \%$ dos municípios que responderam à pesquisa postal informaram ter recebido a orientação inicial de que deveriam constituir um grupo único de trabalho responsável pelo cadastramento de todas as famílias com renda per capita de até 1 / 2 salário mínimo. (BRASIL, 2003m, p. 33)

Essa dificuldade no "fluxo de informações" foi relacionada a quatro fatores combinados: "ausência de consulta prévia aos estados e municípios" no processo de formulação do Cadastro; a não realização de um "teste-piloto" sobre "a viabilidade da sistemática de cadastramento proposta" (inclui adequação do formulário e softwares, geração de relatórios e gerenciamento do banco de dados); falta de manual operacional disponibilizado previamente aos municípios; e "mudanças de orientações ao longo do processo de cadastramento", bem como no formulário e versões do software de entrada de dados, indicando falta de planejamento prévio. (BRASIL, 2003m) Diante disso, o TCU recomenda ao Ministério a ampliação dos canais de comunicação com estados e municípios e elaboração de um "Manual de Procedimentos do Cadastro Único" com orientações uniformizadas, pautadas nas principais dúvidas apresentadas pelos municípios. (BRASIL, 2003m)

Apontam-se ainda deficiências no teleatendimento da CEF para esclarecimento de dúvidas associadas a dois fatores: o canal de atendimento não é exclusivo para o Cadastro e "os atendentes não são suficientemente treinados" nas questões relacionadas a ele. (BRASIL, 2003m) Também há problemas na emissão e na distribuição de formulários, os quais são fornecidos em número insuficiente, indicando uma defasagem nas estimativas utilizadas como parâmetro para o cadastramento. O TCU recomenda que 
novas estimativas tomem por indicadores os dados do Censo 2000, substituindo as que se baseiam no Censo 1991, de modo a corrigir as disparidades. Aponta-se ainda como insuficiente o treinamento dispensado aos cadastradores e digitadores, por seu conteúdo de caráter superficial e aplicado num curto espaço de tempo. Assim, recomenda-se também ao MAPS e à Caixa Econômica "que seja aprimorado e intensificado o treinamento oferecido aos agentes municipais envolvidos no Cadastro Único”, prestando-lhes informações pertinentes às suas incumbências. (BRASIL, 2003m)

O TCU analisou também os efeitos do Cadastro Único sobre a gestão dos programas de transferência de renda, aos quais servia. Verificou-se que nem todos os municípios tinham acesso aos relatórios gerados a partir do Cadastro e que geralmente esses relatórios eram bastante simplificados, não contribuindo para o gerenciamento do programa. Esse fato é atribuído ao tipo de software adotado inicialmente, restrito à tarefa de inserção de dados:

Um dos relatórios oferecidos, por exemplo, informa somente os quantitativos de domicílios rurais e urbanos digitados e de pessoas com e sem documentação cadastradas, por faixa etária. Tais relatórios não contêm, portanto, informações relevantes para a gestão dos programas. (BRASIL, 2003m, p. 39)

Por fim, identificou-se também lentidão no processamento dos dados pela CEF, o que fora atribuído pelo TCU ao compartilhamento dos mesmos recursos de computação entre o Cadastro Único e outras bases pesadas, como FGTS e PIS/PASEP. Além disso, constatou-se a ocorrência de perda de dados, por falhas nos aplicativos utilizados pela Caixa, gerando listagens cujo quantitativo de registros era inferior ao efetivamente encaminhado pelos municípios. Contudo, admite-se que o Cadastro promoveu alguma melhoria no processo de identificação e na localização do público visado. (BRASIL, 2003m)

Observa-se que os problemas identificados nessa auditoria do Tribunal de Contas confirmam as queixas e denúncias debatidas no CNAS em meados de julho daquele mesmo ano (2002), como se viu anteriormente. Em conta disso, pode-se verificar que a criação do Cadastro Único, embora indique a adoção de maior racionalidade na operacionalização dos programas sociais, converteu-se em um problema a mais para a maioria dos municípios. Implantar e operar esse cadastro demandava conhecimentos e recursos que não estavam disponíveis no âmbito local, dos quais o governo federal se eximiu. Os municípios foram obrigados a realizar o novo cadas- 
tramento e, assim, adaptar-se às novas ferramentas sem a devida orientação de como fazê-lo, inclusive sem ter claro quem deveria promover tal orientação, já que a coordenação dos programas era dispersa. Essa obrigatoriedade fez-se ainda mais pesada pela tentativa de aceleração do cadastramento, incorrendo fatalmente no acúmulo de erros e inconsistências nos dados gerados.

As recomendações do TCU feitas a partir dessa auditoria, para criação de canais de comunicação com os municípios, apoio financeiro e técnico, correção das falhas nos aplicativos, criação de uma dinâmica de atualização e manutenção do cadastro e checagem de consistência dos dados, corroboram um diagnóstico realizado no período de transição entre governos, ao final de 2002. Neste ano, o Brasil realizou eleições presidenciais, as quais se polarizaram entre o Partido da Social Democracia Brasileira (PSDB), então à frente do governo, e o Partido dos Trabalhadores (PT), principal partido de oposição. Naquele ano, o país inaugurou uma prática político-administrativa que se pôde julgar capaz de minimizar o efeito de descontinuidade sobre as ações de governo quando da substituição do mesmo: a Medida Provisória (MP) nº 76, de 25 de outubro daquele ano, que criou o mecanismo de instituição de uma "equipe de transição", pelo candidato eleito à presidência da república, vedada a sua realização em caso de reeleição. Essa equipe tinha por objetivo "inteirar-se do funcionamento dos órgãos e entidades que compõem a Administração Pública federal e preparar os atos de iniciativa do novo Presidente da República, a serem editados imediatamente após a posse". (BRASIL, 2002g, Art. $2^{\circ}$ ) Em conta disso, a equipe goza da prerrogativa de ter "acesso às informações relativas às contas públicas, aos programas e aos projetos do Governo Federal”. (BRASIL, 2002g, Art. 2º, $\left.\S_{1} 1^{\circ}\right)$ Com o fim de efetivar essa equipe, foram criados 50 cargos de comissão temporários,$^{50}$ a serem ocupados desde o "segundo dia útil após a data do turno que decidir as eleições presidenciais" e vagos no máximo "até dez dias contados da posse do candidato eleito”. (BRASIL, 2002g, Art. 4ํㅗ § 1ํ)

A Exposição de Motivos que justifica a MP n. .76 (BRASIL, 2002i) data de 2 de outubro de 2002, poucos dias antes, portanto, do primeiro turno das eleições, que ocorreria no dia seis. Nela, afirma-se que a motivação desse ato está na realização de uma "transição ética, transparente e democrática"

50 Cargos Especiais de Transição Governamental (CETG). (BRASIL, 2002g, Art. $4^{\circ}$ ) 
(BRASIL, 2002i), fazendo, ainda, referência ao Decreto n. ${ }^{\circ}$ 4.199, de 16 de abril de 2002, que institui normas para fornecimento de informações sobre $o$ governo a partidos políticos, coligações e candidatos à Presidência até o final das eleições, como primeira medida em favor da constituição desse processo formal de transição.

O PT saiu vencedor nas eleições e, assim, o presidente eleito, Luiz Inácio Lula da Silva, constituiu a sua equipe de transição. A composição dessa equipe foi anunciada aos 12 de novembro de 2002, e teve definida, como teto para a entrega dos relatórios de avaliação que deveria elaborar, a data de 24 de dezembro. (COSTA; ANDRADE, 2003, p. 18) Essa equipe elaborou um complexo diagnóstico sobre a situação em que se encontrava o governo, tendo a área social merecido parte das críticas mais significativas..$^{51}$ Segundo Silva, Yazbek e Giovanni (2008), é a partir desse relatório que se abre o debate sobre a unificação dos programas federais de transferência de renda no Brasil, justificado por uma série de problemas apontados na condução desses programas, sintetizados a seguir:

a. Constatou-se a existência de concorrência entre os programas em vigor, concernente aos seus objetivos e público-alvo, e isso redunda em concorrência entre os órgãos gestores desses programas, e também em diferenciação no tratamento dispensado a uma mesma população; ${ }^{22}$

b. Verificou-se que não havia uma coordenação geral sobre os programas, ou mesmo um planejamento gerencial, gerando prejuízos na sua implementação e, sobretudo, nos resultados alcançados; ${ }^{53}$

$51 \quad$ Embora citado por diversas fontes, este relatório não está acessível. O que ora exponho a seu respeito foi extraído de materiais produzidos a partir de seu conteúdo, publicados ou disponibilizados na internet.

52 Decerto pode-se tomar como exemplo desse fato a comparação entre o PETI, de responsabilidade da Assistência, e o Bolsa Escola, gerido pela Educação, programas, como se viu anteriormente, destinados a um mesmo público, mas excludentes entre si e cujos valores transferidos aos beneficiários eram bastante diferenciados.

53 Essa observação coincide tanto com as queixas apresentadas no debate do CNAS, em julho de 2002, quanto com os resultados expostos no Relatório de Auditoria do TCU, referentes àquele mesmo ano, quando trata das solicitações dos municípios para realizar alterações no cadastro dos beneficiários, que eram destinadas a diferentes órgãos. 
c. A falta de estratégia de autonomização para as famílias egressas dos programas foi outro problema apontado, indicando-se que cada programa findava em si mesmo, sem vinculação a políticas efetivamente emancipatórias;

d. O mesmo diagnóstico reconheceu a importante inovação representada pela adoção de políticas de transferência de renda não contributivas, mas apontou os limites dados por sua gestão, pautada num modelo tradicional de fragmentação, setorialização, desarticulação e superposição;

e. Verificou-se também que a implementação dos programas se dava geralmente por quadros de servidores não vinculados aos setores responsáveis, impedindo a profissionalização do pessoal efetivo, condição para a continuação das ações;

f. Havia problemas nas relações com os municípios, concernentes à exigência de contrapartida, não considerando o porte e as condições de cada município. No caso do PETI, isso se expressa no cofinanciamento da bolsa e da jornada ampliada e, de forma geral, na realização do cadastramento de beneficiários;

g. As metas subestimadas para a inserção de beneficiários nos programas eram condicionadas à baixa alocação de recursos do Orçamento. Como se viu no Relatório de Auditoria, o TCU, chegando a conclusão semelhante, recomendou a correção nas estimativas de famílias pobres, ante a insuficiência de formulários cadastrais em relação à demanda existente;

h. Ainda como consequência do baixo valor orçamentário, foi apontado o valor irrisório dos benefícios concedidos, não gerando modificação significativa nas condições de vida das famílias beneficiárias;

i. Por fim, foram apontados problemas com o Cadastro Único, que, aliás, fora dito como sendo o "ponto de estrangulamento" para a implementação dos programas: "programa [software] desenhado para municípios de pequeno porte (cerca de 500 famílias); o 
programa rejeita importação de dados cadastrais de outras fontes; centralização dos dados na CEF; formulário complexo, preenchido em pequeno espaço de tempo e sem a devida capacitação do pessoal; o programa não apresenta módulo de manutenção e atualização”. (SILVA; YAZBEK; GIOVANNI, 2008, p. 132-133)

O quadro descrito confirma um diagnóstico já traçado anteriormente e demonstra que, durante o ano de 2002, não se avançou na correção dos problemas gerados na implementação dos programas de transferência de renda, especialmente no que diz respeito à identificação do público-alvo desses programas. Tanto assim que as recomendações apresentadas pela equipe de transição para superação dos problemas - e que, segundo os autores aqui referidos, servirão de base à futura unificação dos programas em questão - em grande parte referem-se direta ou indiretamente ao Cadastro Único.

Apontou-se para a necessidade de "consolidação e validação" do Cadastro, através da reformulação do instrumento de coleta, em favor de um melhor "planejamento local e nacional". De outro lado, sugeriu-se a revisão do papel designado à Caixa Econômica, de "agente operador e pagador". Sugeriu-se ainda a definição de um corte de renda comum a todos os programas na seleção de seus beneficiários, bem como a atualização das estimativas acerca dessa população. Destaque-se ainda a indicação para o retorno da "base de dados enviada pelo cadastramento único" aos municípios, de modo a servir efetivamente ao planejamento local. (SILVA; YAZBEK; GIOVANNI, 2008)

No encadeamento das ações de unificação dos cadastros e da adoção de um único cartão, já vigentes, aponta-se para a necessidade de articulação entre os diversos programas sociais e indicam-se alternativas de aproximação entre as coordenações dos mesmos. (SILVA; YAZBEK; GIOVANNI,

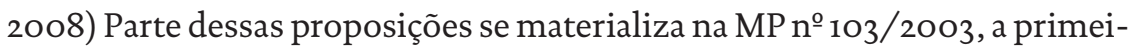
ra emitida pelo novo governo e que promove uma reforma administrativa, instituindo aí o MAPS, substituindo a antiga SEAS, e em cujo conjunto de atribuições incluiu-se a "articulação, coordenação e avaliação dos programas sociais do governo federal” (BRASIL, 2003e, Art. 27, inciso II, alínea d), mas essa ainda não será uma medida capaz de romper com a concorrência interministerial pelos programas sociais e pelos cadastros correspondentes, 
principalmente porque o próprio governo adotará outras medidas que se mostrarão contraditórias ao discurso contrafragmentação.

\section{DILEMAS DO NOVO GOVERNO NA IMPLEMENTAÇÃO DE PROGRAMAS SOCIAIS A PARTIR DAS INFORMAÇÕES DO CADASTRO ÚNICO}

O discurso do período de transição, de uma forma geral, corrobora o Programa de Governo do presidente eleito (Luiz Inácio Lula da Silva), apresentado em 2002. No tópico desse programa dedicado à "inclusão social”, afirmava-se a necessidade de tomar as políticas sociais como "eixo do desenvolvimento", rompendo com os vieses assistencialista, fragmentário e clientelista, sob os quais essas políticas historicamente teriam se desenvolvido. Salientou-se o alcance limitado que tinha a proteção social brasileira, por seu caráter contributivo e voltado, portanto, apenas aos empregados formais. Assim, definiu-se como prioridade do pretendido governo realizar ações voltadas ao emprego, à distribuição de renda, à questão tributária e a programas de renda mínima. Como estratégia de inclusão, e sob a premissa de que a pobreza no Brasil não tem caráter residual, anunciou-se ali a perspectiva de superar a fragmentação e a focalização dos programas sociais, através da implementação de políticas integradas e de caráter universal. (ESPECIAL..., 2002) $)^{54}$

Após tomar posse, a principal medida adotada pelo novo governo para efetivar suas propostas na área social foi a criação do programa Fome Zero, um projeto petista em discussão desde o ano 2001, tendo como prioridade erradicar a fome no país. O Fome Zero estruturou-se em quatro eixos fundamentais, donde se sequenciariam programas e ações para o seu cumprimento:

1. Acesso a alimentos, incluindo os programas de transferência de renda, dentre outros;

2. Fortalecimento da agricultura familiar, com ações voltadas à geração de renda e à produção no campo;

54 Ver em: <http://www1.folha.uol.com.br/folha/especial/2002/governolula/presidente.shtml> 
3. Geração de renda, para incentivo à economia solidária e qualificação profissional e;

4. Articulação, mobilização e controle social, visando parcerias entre sociedade e Estado, para alcançar os objetivos do programa. (BRASIL, 2010 $)^{55}$

Voltado especialmente à população de baixa renda, a execução do programa dependia de informações específicas sobre essa população, o que, em tese, o remetia diretamente à utilização do Cadastro Único. Mas esse era a mesma base de dados, ou seja, o mesmo cadastro sobre o qual já se tinham feito contundentes críticas, o que colocaria o novo governo ante um dilema: usar as informações que já se sabia inconsistentes, sob o risco de comprometer a sua política, ou construir um novo cadastro e ignorar, por outro lado, todo o investimento que já se havia feito para construir a base de dados existente, que em valores monetários, segundo notícias da época, girava em torno de 100 milhões de reais. (BRAGON-2003) No início de 2003, o Cadastro reunia cerca de 5,4 milhões de famílias, o que representava aproximadamente $60 \%$ da população pobre, estimada, então, em 9,3 milhões (de famílias). (BRAGON, 2003) As críticas não se remetiam, porém, apenas ao contingente de famílias cadastradas, mas, sobretudo, à qualidade dos dados armazenados, à sua capacidade efetiva de identificar quem eram os verdadeiros pobres do Brasil.

A primeira ação do Fome Zero limitou-se a uma experiência piloto, de implantação do Programa Nacional de Acesso à Alimentação (PCA), o Cartão Alimentação, ${ }^{6}$ em dois municípios do Piauí: Guaribas e Acauã, beneficiando 500 pessoas em cada um deles. Este era um programa de transferência de renda que, à semelhança de outros já existentes - como o Bolsa Alimentação -, destinou-se às "famílias pobres”, aquelas com renda per capta de até meio salário mínimo. (BRASIL, 2003a, Art. $4^{\circ}$ ) Inicialmente a opção do governo era atender preferencialmente pessoas que ainda não tivessem acesso a qualquer benefício federal, o que aumentava a resistência

55 Ver em: <http://www.mda.gov.br/sitemda/sites/sitemda/files/user_arquivos_64/pageflip-4204234487363-lt_Fome_Zero_A_experinc-1750637.pdfs.

56 O PCA foi criado pela Medida Provisória $n^{\circ}$ 108, de 27 de fevereiro de 2003. Quando da sua conversão em lei (n. ${ }^{\circ} 10.689$ ), em 13 de junho de 2003 , o programa passou a ser chamado de Programa Nacional de Acesso à Alimentação (PNAA). 
à utilização do Cadastro Único. Mas essa opção gerava outro problema: o da logística de pagamento de benefícios que, no caso dos demais programas, a CEF já dispunha. (FUTEMA, 2003a) Ao fim, parte dos selecionados nas cidades piauienses constava mesmo dos registros do Cadastro Único, mas cerca de metade foi incluída por um novo cadastramento, sob a responsabilidade de um "comitê gestor local", considerando que muitas famílias cujo perfil atendia aos critérios do novo programa estavam fora do cadastro principal. (SALOMON, 2003b) Quando o governo regulamentou o PCA (BRASIL, 2003a), definiu o Cadastro Único como mecanismo de seleção dos seus beneficiários (BRASIL, 2003a, Art. $5^{\circ}$, § \ $1^{\circ}$, Art. 10, § Único, inciso IV), mas consolidou a autoridade do Comitê Gestor Local (CGL) (BRASIL, 2003a, Art. $\left.9^{\circ}\right)$, representando a instância de controle social do programa, composta por representantes do governo e da sociedade civil, com o fim de confirmar a listagem contendo a identificação das famílias selecionadas.

O comitê era uma estrutura nova, mas já fora criada com certo acúmulo de atribuições. Embora instituído pelo município e monitorado por este, ele teve sua autoridade designada pelo ministério responsável pelo programa - Ministério Extraordinário de Segurança Alimentar e Combate à Fome (MESA) -. É assim que a definição das famílias a serem cadastradas sai, em tese, da indicação direta da administração municipal para o crivo do Comitê. E é em vista disso que a ampliação do programa exigirá dos municípios conveniados a criação desses comitês (BRASIL, 2003a, Art. 10), recurso supostamente capaz de impedir o uso eleitoreiro do cadastramento, do que se acusou o Cadastro Único noutrora. (EXPANSÃO..., 2003) Porém, a despeito das críticas apresentadas ao CadÚnico, e mesmo com o novo mecanismo de controle, o cadastramento para o Cartão Alimentação parece ter seguido caminho semelhante, pois, tendo sido realizado num curto espaço de tempo, seus procedimentos apresentaram problemas, identificados quando do pagamento dos benefícios. A exemplo disso, à época noticiou-se que, em Acauã, algumas famílias cujos registros foram homologados pelo comitê gestor foram substituídas por outras sem o conhecimento do comitê (KORMANN, 2003), fato que punha em dúvida a pertinência das novas estruturas criadas.

Essas e outras questões vão nutrir o debate no âmbito da assistência durante o ano 2003. A exemplo disso, em meados de abril, numa reunião conjunta do Conselho Nacional de Assistência Social (CNAS) com os Con- 
selhos Estaduais de Assistência Social (CEAS), ${ }^{57}$ retomou-se a discussão sobre os programas sociais do Governo Federal, e o programa Fome Zero ocupou um tópico específico do debate. A representante do MESA, Sra. Maya Takagi, convidada para explanar sobre o programa, considerou como aspecto fundamental do Fome Zero o fato de ele constituir-se em "um programa de todo o governo", nas três esferas federativas, e com a participação da sociedade civil. (BRASIL, 2003i, p. 39) Um programa que integra uma proposta para "implantar uma política de segurança alimentar e nutricional permanente”. (BRASIL, 2003i, p. 40) O controle social seria uma de suas características mais marcantes, principalmente por propiciar a participação dos próprios beneficiários, evitando favorecimentos indevidos, como os verificados em outros casos: "deve haver maior controle social nos critérios de seleção das famílias beneficiárias, pois, muitas vezes, acaba havendo discriminação política, e vemos isso ocorrer em muitos municípios". (BRASIL, 2003i, p. 41) O aspecto principal desse controle estaria, então, na observação dos critérios utilizados para definir "quem eram os pobres", quem deveria ser contemplado pelo cadastramento e, consequentemente, pelos benefícios do programa.

A expositora considerou também que o país não dispunha naquele contexto de políticas de acesso à alimentação, as quais teriam sido "substituídas por políticas de transferência direta de renda” (BRASIL, 2003i, p. 44) no início da década, medida que teria trazido o importante componente de impedir o uso político de ações públicas, como a doação de cestas básicas, mas reconhece que simultaneamente teria criado dificuldades para a inclusão de parte do público-alvo, devido à exigência de documentação civil para inserção dos indivíduos no sistema cadastral. Dessa forma, o Cartão Alimentação (primeira ação do programa Fome Zero) deveria voltar a sua atenção para esse público, criando condições para a sua inclusão. E o Comitê Gestor deveria ter como atribuição primeira, nesse sentido, "validar a lista dos beneficiados" (BRASIL, 2003i) para o novo programa.

Nos programas de transferência de renda há um grupo vulnerável, até então fora da nossa rede de produção social [sic]. Refiro-me às famílias

$57 \quad$ A reunião conjunta deu-se no interior da $101^{\mathrm{a}}$ reunião ordinária do Conselho Nacional de Assistência Social (CNAS), entre 15 e 16 de abril de 2003. 
sem documentação básica e que, por isso, não podem entrar no sistema do Cadastro Único. Exatamente aqueles que não têm sequer registro civil são os mais excluídos da sociedade. Com a ajuda da sociedade civil local, esse programa está voltado também para promover uma grande campanha de registro de nascimento. (BRASIL, 2003i, p. 44)

Esse dado aponta para uma fragilidade importante do Cadastro Único: a barreira legal para alcançar as famílias que estavam na última escala da condição civil, ou mesmo fora dessa condição, uma vez que não existiam formalmente. Isso expunha o fato de que os programas sociais não estavam chegando aos considerados efetivamente mais pobres e demonstrava a insuficiência do Cadastro para identificar essa população. Por outro lado, a vigilância do Comitê Gestor deveria pôr em evidência esse problema e suscitar do poder público medidas para a sua resolução. Em suma, o controle exercido pelo Comitê dar-se-ia majoritariamente sobre a eficácia do Cadastro Único, como instrumento legítimo para confirmar ou não o enquadramento das famílias cadastradas na condição de pobreza.

Mas as atribuições do CGL não se limitavam a isso, porque o mesmo Comitê deveria também fazer o acompanhamento do programa, monitorar o desenvolvimento das famílias e avaliar a aplicação do benefício exclusivamente em alimentação. (BRASIL, 2003i) ${ }^{58}$ Com tais atribuições, coincidentes com as de outras instâncias de controle social, a exemplo dos conselhos municipais de assistência social, os conselheiros da assistência puseram em questão a pertinência dessa nova instituição que, tendo caráter consultivo, acumulava funções de conselhos deliberativos preexistentes. (BRASIL, 2003i) Na avaliação do MESA, porém, o controle anterior não se dava efetivamente, pois não havia a participação dos reais interessados e, consequentemente, excluíam-se muitas famílias que deveriam ser prioritárias. Esse fato teria sido verificado, por exemplo, na implantação do PCA em Guaribas e Acauã.

A proposta é mesmo a de que a sociedade valide a lista do Cadastro Único. Por exemplo, das mil famílias beneficiadas inicialmente, verificou-se que quinhentas não estavam no cadastro, não recebiam nenhum programa, não estavam na rede de proteção social do governo, mas eram

58 OPCA foi um programa essencialmente polêmico, porque impôs a exigência de comprovação de gasto do benefício exclusivamente com alimentação (FUTEMA, 2003b), guardada ainda a possibilidade de sua transferência em alimentos, e não em dinheiro. (BRASIL, 2003a, Art. $2^{\circ}$ ) 
extremamente pobres, com uma renda per capta de 10 a 20 reais, segundo informações do Comitê Gestor, das pessoas que estão no município. Colocá-los no papel de atores foi fundamental. Deu uma nova cara ao programa, pois as pessoas falaram que quem sempre determinava era o prefeito. Não existia uma participação da sociedade, as lideranças sociais não assumiam esse papel consultivo. Isso foi feito pela primeira vez. (BRASIL, 2003i, , p. 54, grifo do autor)

O Comitê Gestor teria, então, também um caráter deliberativo e não estaria efetivamente em conflito de atribuições com os demais conselhos, porque fora criado fundamentalmente em função do novo programa.

O Comitê Gestor do Cartão [Alimentação] é deliberativo porque valida a lista de famílias. Ele avalia, vê se há famílias duplicadas, famílias sem documentação, se é preciso pedir documentação, cadastrar família, se aquela família não é pobre, se é amiga do prefeito, enfim, esse tipo de coisa. É deliberativo, mas é um Comitê gestor de caráter executivo, um parceiro do programa. (BRASIL, 2003i, p. 55)

\section{CENTRALIDADE DE UM CADASTRO DOS POBRES PARA ALCANÇAR A EFETIVIDADE NA TRANSFERÊNCIA DE RENDA FOCALIZADA}

As medidas adotadas pelo governo a partir do PCA não foram suficientes para eximi-lo de críticas, fosse no âmbito restrito do Conselho de Assistência, fosse nas notícias veiculadas pela imprensa, de acesso livre ao público. Ao contrário, o caminho escolhido dava vagas à interpretação de que a superação da fragmentação anteriormente proposta não estava sendo posta em prática, pois, em última instância, criaram-se novos ministérios (MAPS, MESA), um novo programa (PCA) e uma nova instância de controle social (CGL). Para reverter essa situação, o governo precisava, e buscou, o que se chamou na imprensa de "guinada social", que deveria se operar a partir da unificação dos programas de transferência de renda em vigor. Essa estratégia criaria um único programa, com coordenação centralizada e sem a imposição da forma como gastar o dinheiro do benefício, além de exigir o cumprimento de condicionalidades em saúde e educação. (SALOMON; ATHIAS, 2003)

O ponto de partida para essa "guinada" parece estar identificado num outro documento, elaborado pelo Ministério da Fazenda: "Política Econô- 
mica e Reformas Estruturais", publicado em to de abril de 2003. Um dos temas ali discutidos remete-se às "políticas sociais e redução das desigualdades". O documento afirma que falta efetividade nas políticas sociais no Brasil, no sentido de que não se verifica a sua "capacidade de transformar o quadro de pobreza” instalado. (BRASIL, 2003h, p. 49) A orientação é para que se corrijam as "graves distorções" existentes tanto na "estrutura tributária” quanto na "focalização" e na "eficácia dos programas sociais”, uma vez que os gastos públicos seriam vultosos, mas mal geridos e dirigidos em parte aos “não-pobres". (BRASIL, 2003h, p. 14)

Sob essa perspectiva, entendia-se que a forma de distribuir os recursos disponíveis alimentava as desigualdades, redundando em "precariedade" do "grau de focalização", decorrente de três falhas específicas: o "desenho dos programas sociais", que permite acesso dos "não pobres"; os critérios para a distribuição regional dos recursos e a "dificuldade de identificação local da população pobre”. (BRASIL, 2003h, p. 51) Complementa esse quadro, a ausência de um "sistema de avaliação" sobre as políticas e programas sociais no país: "é necessário um esforço permanente de avaliação, o qual permitirá, por sua vez, a concentração de recursos em um espectro menor de programas com maior efetividade”. (BRASIL, 2003h, p. 51, grifo nosso) Há, então, que se "direcionar esforços para a sistematização de informações e o aperfeiçoamento de sistemas de avaliação" (BRASIL, 2003h, p. 52) para o enfrentamento da pobreza e das desigualdades no país.

Os aspectos principais constantes desse documento aparecem já no discurso da Ministra de Assistência e Promoção Social, Benedita da Silva “A política e a organização da Assistência Social" -, na 101ª reunião ordinária do CNAS, no dia 16 de abril de 2003, ${ }^{59}$ sugerindo uma forte identificação das premissas adotadas por aquele Ministério (MAPS) e as diretrizes da política econômica do país.

Como todos sabem, nós encontramos ações fragmentadas na área da assistência social, com as quais não tínhamos condição sequer de focalizar nosso público-alvo, que sabíamos ser formado pelas pessoas que estão abaixo da linha de pobreza e pelos segmentos excluídos da sociedade. Por conseguinte, era preciso formular e implementar um sistema de avaliação da política que encontramos e também da política social do nosso governo. (BRASIL, 2003i, p. 194-195)

59 A mesma reunião realizada em conjunto com os CEAS. 
Nesses termos, a Ministra identificava como atribuição do MAPS a articulação e a avaliação de todas as ações sociais do Governo, no intuito de formular uma política de Assistência Social para o país. A proposta do Ministério, nesse sentido, era a de "desenvolver um Plano de Atendimento Integral à Família” (BRASIL, 2003i, p. 195), como forma de identificar e focalizar o público da Assistência. Na esteira desse plano, pretendia-se elaborar um "relatório de condições de vida", pautado numa perspectiva clara: "as pessoas que queremos alcançar são aquelas cujas condições de vida identificamos como miserável”. (BRASIL, 2003i, p. 196) A partir disso, o Governo seguiria na elaboração de um "Atlas Social”. Ou seja, em conjunto, dada a natureza prévia focalizada da atenção pública, o que se põe é que, para a formulação de uma política de assistência social, da qual se julga o país carecer, o ponto de partida seria a construção de informações sobre o público-alvo base de implementação e eficácia dessa política.

Daí, a "validação e implementação do Cadastro Único" assume centralidade na gestão dos programas. Mas, a despeito do caráter integrado que se lhe atribuía, não se operava efetivamente esse Cadastro: "cada Ministério tem o seu cadastro. Eles não se falam; não há entre eles cruzamento de informações". (BRASIL, 2003i) Em outras palavras, o Cadastro, embora "Único", era utilizado de forma particular por cada Ministério, obedecendo a critérios específicos segundo os objetivos de cada programa. Uma vez que ele se constituía na base de informações sobre a qual definia-se a concessão dos benefícios dos programas de transferência de renda, as pessoas que não estivessem ali inclusas estariam automaticamente excluídas dos benefícios desses programas. Assim, ao tempo em que alguns recebiam benefícios sobrepostos, outros sequer os recebiam.

Por isso, nós nos deparamos com um atendimento que não poderíamos de forma nenhuma medir, já que o cadastro não está ao alcance de todos, regionalmente falando. Nós nos deparamos com uma família pobre ao lado de outra família igualmente pobre e observamos que uma delas recebia benefícios de vários ministérios e a outra, ao lado, nas mesmas condições, não era atingida por nenhuma ação voltada para as suas demandas. (BRASIL, 2003i, p. 196-197)

Seria tarefa imprescindível do Governo, então, a unificação de todos os cadastros, pois isso era condição para identificar a população pobre (ou “miserável”) do país, e deveria se dar a partir do cadastro do Ministério da Assistência (formado especificamente pelo público da assistência), reco- 
nhecendo-se, porém, as dificuldades a serem enfrentadas nesse processo, decorrentes da necessidade de intrusão em outros Ministérios. (BRASIL, 2003i) Em par com essa tarefa, pretendia-se "elaborar a proposta de um programa unificado de transferência de renda condicionada" (BRASIL, 2003i), igualmente para solver problemas herdados da gestão anterior, e reconhecidamente mantidos no governo atual: "existe uma falta de eficácia no nosso trabalho" (BRASIL, 2003i, p. 199-200), afirmava a Ministra, como que parafraseando o diagnóstico do Ministério da Fazenda, onde se considerava que, para se alcançar a "efetividade" das políticas sociais, haveria que se conjugar eficiência, eficácia e focalização. No que tange à unificação dos programas, porém, a discussão pareceu estar ainda em estágio preliminar, sem uma definição clara dos contornos que teria o programa unificado, situação que se manteria ainda por alguns meses.

Essa unificação dos programas prometia ser uma vacina eficaz para a superação dos problemas decorrentes da estrutura existente de vigência de vários programas de transferência de renda, e um desses problemas estava no gasto que a operação dessa estrutura demandava. Segundo Athias (2003a), durante o ano 2002, a CEF teria faturado $\mathrm{R} \$ 183$, 2 milhões de reais na prestação desses serviços, dos quais $\mathrm{R}$ \$ 104 milhões referentes apenas ao Cadastro Único. Outro problema estava no registro irregular de pessoas fora do perfil dos programas, problema esse do qual o Cartão Alimentação se contaminou ao lançar mão do mesmo Cadastro. A exemplo disso, na data em que se contavam cem dias da implantação do PCA, com a sua expansão a outros estados (para além do Piauí), publicaram-se notícias indicando fraudes em municípios cearenses, onde secretários municipais e vereadores estariam recebendo indevidamente o benefício. (FERNANDES, 2003)

Portanto, no conjunto, são os problemas referentes à execução e validade dos dados do Cadastro Único que aparecem na superfície da discussão sobre a unificação dos programas sociais. Mas o pano de fundo para o Ministério da Assistência, bem como para os conselheiros do CNAS, parece ter sido a coordenação das ações do Governo na área social, aspecto tido como fundamental no processo de fortalecimento de uma política de Assistência. Embasando-se nas diretrizes de organização da Assistência Social descritas na LOAS, que prevê um comando único para as ações sociais (BRASIL, 1993, Art. 5ํ․ I), supunha-se que o Ministério da Assistência Social (MAS), 
antigo MAPS, ${ }^{60}$ deveria coordenar a política social do novo Governo, debate alentado principalmente pelo fato de o CNAS não estar participando da formulação ou tomadas de decisão sobre as políticas sociais.

Entre os dias 1o e 11 de junho (2003), na $103^{2}$ reunião do Conselho, esse foi um dos temas postos em pauta. A discussão viera em reação à divulgação, na imprensa, da criação de um "setor social" na Casa Civil, o qual coordenaria os programas de transferência de renda após a unificação, fato insuflador de uma disputa que se desenhava desde o início do Governo.

A Comissão de Política [do CNAS] propõe que seja aprovado neste Plenário uma manifestação a favor da manutenção de programas de transferência de renda na Política de Assistência Social e que eles sejam coordenados pelo Ministério de Assistência Social. (BRASIL, 2003j, p. 23)

Essa discussão se deu em conjunto com outra, que tinha fito semelhante, a do Plano Plurianual (PPA), reivindicando-se a integração do CNAS no processo de sua formulação. As comissões internas do Conselho buscavam entre si um consenso quanto à forma de tratar a questão, e decidiu-se pela discussão em plenário, a partir da explanação de um representante do MAS sobre o Plano.

Essa explanação ocorreu na reunião seguinte do CNAS (entre os dias 15 e 17 de julho de 2003). Foi exposto que as ações sociais do governo, no PPA, estavam distribuídas em distintos programas setoriais, mecanismo pelo qual se impunha que determinados ministérios desenvolvessem ações vinculadas a programas de outros. Mas isso não implicaria necessariamente numa ação integrada desses diferentes ministérios, pois o PPA propunha a manutenção da especificidade de cada programa, distinta da noção de uma rede de proteção, visando garantir maior visibilidade às ações realizadas em cada área especificamente, como idoso, criança etc. (BRASIL, 2003k) Nesse ponto, faz-se a ressalva de que a proposta de unificação dos programas de transferência de renda ainda não estava concluída e, em razão disso, não constava no PPA da Assistência, o que justificaria a manutenção de ações fragmentadas.

Àquela altura, predominava ainda a dúvida quanto ao órgão que seria responsável pelo programa unificado, mas, uma vez que o MAS coordenava

6o A denominação do ministério foi alterada pela Lei $n^{\circ}$ 10.683, de 28 de maio de 2003 (Art. 25, inciso II). 
o processo junto com a Casa Civil, a expectativa era de que ficasse mesmo na área da Assistência.

Como ainda não temos certeza de que ficará neste ministério, elencamos diferentes ações que envolvem transferência de renda, sabendo que isso poderá ser modificado. Estamos coordenando esse trabalho com muito interesse, com muito carinho porque é importante esse passo de não haver a pulverização dessa transferência de renda. A transição desse modelo fragmentado para um modelo unificado não é simples - parece simples, mas não é. (BRASIL, 2003k, p. 280-281)

A expositora ressaltou também que ainda não havia nome definido para a ação que a constituiria, constando já no PPA como "benefício de renda básica assistencial”. (BRASIL, 2003k, p. 283) Em par com isso, o "cadastro unificado" é lançado no PPA do MAS, vinculado ao programa de gestão das políticas de assistência, alterando a proposição inicial de vinculá-lo ao programa de avaliação. (BRASIL, 2003k ) Esse é um programa ("gestão”) que se repete na estrutura de cada ministério, onde se colocam, segundo a expositora, "todas as questões relativas à manutenção do órgão e suas atividades-meio”. (BRASIL, 2003k p. 287) Assim sendo, o cadastro que aí aparece corresponde especificamente ao cadastro da Assistência, mas é tratado como sendo unificado.

No mês de agosto de 2003, a imprensa noticiava a iminência do programa unificado, já com alguns contornos e características definidos. O critério principal para a seleção das famílias beneficiárias seria o nível de renda, estabelecido inicialmente em $\mathrm{R} \$ 50$ reais per capta, o que o diferenciava bastante de todos os seus antecessores, que, ao serem criados, tinham o valor de meio salário mínimo ou equivalente como referência. Por outro lado, a unificação deveria permitir o aumento do valor do benefício, mas, em razão de restrições orçamentárias, limitar-se-ia o número de beneficiários. Assim, priorizou-se o segmento mais pobre, o que significa dizer que se acentuou o nível de focalização. (ATHIAS, 2003b) Admitiram-se duas categorias de beneficiários: "extremamente-pobres" e "pobres", correspondendo às famílias com renda per capta de até $\mathrm{R} \$ 50$,00 e até $\mathrm{R} \$ 100,00$ respectivamente, o que aparentemente abria a possibilidade de exclusão ou de destituição das famílias já beneficiárias, cuja renda per capta alcançava meio salário mínimo, $\mathrm{R} \$ 120$ reais em 2003. (SALOMO, 2003c)

Os aspectos gerais do programa unificado foram também discutidos no CNAS. Entre os dias 16 e 17 de setembro de 2003, na 106 reunião do 
Conselho, participou o Secretário-Executivo do MAS, Ricardo Henriques, com exposição sobre o novo "programa de transferência de renda com condicionalidades", no qual atuou diretamente como "formulador" (BRASIL, 20031, p. 217) Segundo Henriques, esse programa dava sequência às diretrizes adotadas para o conjunto das políticas sociais do Governo Federal, classificadas em três eixos: a) planejamento e avaliação; b) participação e cidadania e c) coordenação e integração. (BRASIL, 2003l, p. 194) O primeiro eixo (planejamento e avaliação) compõe-se de três etapas: desenvolvimento de um sistema de informações e indicadores sociais - um "radar social" - a partir de dados do IBGE e do IPEA; desenvolvimento de um "atlas da política social”, com levantamento do conjunto dos programas sociais implementados no país nas três esferas federativas, uma "cartografia da ação pública na área social” (BRASIL, 2003l, p. 195) e, por fim (ainda para o eixo de planejamento e avaliação), haveria que se desenvolver um "sistema de avaliação da política pública na área social”, para averiguar "eficiência, eficácia, impacto, adequabilidade e sustentabilidade” dessa política. (BRASIL, 2003l, p. 196)

[...] é impossível resgatar com sobriedade a política social e considerá-la no mesmo patamar de respeito que a política econômica se não tivermos esses elementos mínimos que permitam desenhar com mais ciência, no sentido pleno da palavra, a política social. (BRASIL, 2003l, p. 196)

Quanto ao segundo eixo, participação e cidadania, o governo parte da noção de que o controle social pode garantir qualidade à política implementada e maior eficácia em seus resultados, pelo que haveria que se viabilizar a capacitação de gestores locais sob essa perspectiva. A coordenação e integração (terceiro eixo) toca a questão da dispersão e sobreposição de ações, da ausência de um "sistema matricial" para essas ações, seja no âmbito da União, seja no que tange à interlocução entre as três esferas. (BRASIL, 2003l) Em seu conjunto, essas diretrizes foram apresentadas como uma resposta ao contexto conturbado em que se desenvolviam as políticas sociais e aos usos indevidos que delas se faziam.

Na medida em que a política é fragmentada, a relação do Poder Público com a sociedade desvaloriza a possibilidade de interlocução integrada e coesa da sociedade civil, fragmenta a relação com unidades individuais, cria um véu sobre a percepção do todo, gera um sistema absolutamente assimétrico no fluxo de informações, portanto, diante dessa nebulosidade, cria-se uma base sólida para implementarem políticas de tradição assistencialista. (BRASIL, 2003l, p. 199) 
Dessa forma, haveria que se ter uma ação no sentido de reduzir a fragmentação e a setorização das políticas, evitando a intrusão de "interesses locais, políticos e imediatistas" na sua operação, e quebrando a "paternidade setorial dos pobres”. (BRASIL, 2003l, p. 199) Haveria que se ter uma "política de governo de transferência de renda”, um programa único de transferência com condicionalidades, pautado nos objetivos de reduzir a pobreza e propiciar “acesso aos direitos sociais universais”. (BRASIL, 2003l, p. 200)

É impossível coordenar política social se as políticas de transferência de renda forem setorializadas, porque, a priori, não há um instrumento mínimo de transferência de renda dentro de uma lógica única e coordenada. [...] Sem falar na Assistência, se Saúde e Educação tiverem, cada uma, um programa de transferência, será absolutamente impossível, porque cada uma elege o seu público-alvo, os seus segmentos de fragilidade, definindo endogenamente como realizar a política, portanto não haverá campo de interação real da saúde e da educação. (BRASIL, 2003l, p. 199)

No cumprimento de seus objetivos, o programa, orientado pelo "princípio da equidade", deveria priorizar "os mais pobres entre os pobres", de modo a corrigir a trajetória histórica de exclusão e usar das condicionalidades como mecanismo de acesso aos direitos sociais. Adotar-se-ia, ainda, "um sistema único de pagamento", através de "um único cartão", base para se criar "um número de identificação social”, igualmente único, de caráter nacional, integrando os números do PIS/PASEP, na construção de uma identificação comum para o sistema de seguridade social brasileiro. "Com um cadastro e uma identificação bem feitos, será criada a base para haver uma 'numeratação' [sic] única, pela primeira vez, de seguridade social neste país”. (BRASIL, 2003l, p. 202)

Nesse sentido, o Cadastro Único ganha de novo centralidade na busca da eficácia de operação de programas sociais, constituindo-se no principal instrumento de planejamento da política social no Brasil.

[...] haverá um investimento sólido, agora não mais somente como atribuição de coordenação de várias atuações setoriais, mas uma unidade só coordenando o cadastro, sob o entendimento de que não é possível permanecer na situação obscurantista de que o cadastro era um elemento visível somente para o Governo. A idéia é validar o cadastro antigo [...].

Mudaremos todo o sistema de capacitação desse cadastramento, criaremos um controle de qualidade mínimo, transformaremos esse cadastro num instrumento sólido não só para o Programa de Transferência 
de Renda, mas para o planejamento da política social. Ao validar esse cadastro, ele retornará aos estados e municípios, transformando-se em instrumento de planejamento e gestão da política pública local. (BRASIL, 2003l, p. 202-203)

A "unidade" de coordenação do novo programa e, consequentemente, do cadastro (ou vice-versa) não será a Assistência, como se esperava, mas uma secretaria executiva vinculada à Presidência da República, unificando “o sistema de seleção, de pagamento, de cadastro e de gestão" (BRASIL, 20031, p. 205), reafirmando a lógica antissetorização e antifragmentação. Um “conselho gestor interministerial”, em cuja composição estará também o Ministério da Fazenda, definirá as diretrizes do programa, a serem implementadas pela secretaria executiva.

No debate que se seguiu à exposição do Secretário-Executivo do MAS, dentre as questões colocadas pelos conselheiros da assistência, destacam-se o corte de renda - não citado ali, mas já divulgado na imprensa - e os critérios definidores do público-alvo do programa:

[...] que critérios foram utilizados para a definição desse conceito de pobreza e de extrema pobreza? [...] esse mesmo critério poderia ser utilizado para a definição do público-alvo a ser atendido pelas entidades beneficentes da assistência social [?] (BRASIL, 2003l, p. 211)

Os conselheiros cobraram atenção ao papel dos municípios, indicando que os mesmos estavam colocados fora da esfera decisória, ao tempo em que teriam responsabilidades delegadas na operação do programa: "foi muito comentada aqui a frase ‘conversamos com os governadores'. Mas governador não faz Cadastro Único, não atende à população, não é à porta do governador que o pobre bate, mas à porta do município”. (BRASIL, 2003l, p. 212)

E, tratando-se de Cadastro Único, outras questões se colocam, e uma delas diz respeito às suas limitações para alcançar a totalidade da população visada, especialmente por conta dos critérios estabelecidos para o cadastramento. O que está posto, no conjunto, é que o Cadastro Único não era visto como um instrumento consistente para a implementação daquele programa.

Sabemos de todos os problemas que o Cadastro Único sofreu com a sua implementação. Os municípios tiveram um número reduzido de cadastros de famílias, porque foi determinado um limite de inscrição no 
Cadastro Único para cada município, não existe ali um espelho de toda a pobreza municipal. (BRASIL, 2003l, p. 216)

O Secretário-Executivo do MAS, respondendo às questões colocadas, destacou a importância dos municípios no sistema de gestão do novo programa, no sentido de garantir a participação e o controle social sobre o mesmo. O governo federal, nesse sentido, deixaria a critério da administração local a decisão quanto ao órgão que seria o interlocutor municipal do programa. "Temos uma certa prudência para não atropelar e criar uma camisa-de-força que inviabilize isso”. (BRASIL, 2003l, p. 219) Quanto à linha de pobreza, afirmou que se iniciou por "romper a indexação ao salário mínimo", considerada por ele uma "atrocidade" conceitual e, na ausência de uma "linha" oficial - a qual estaria em processo de elaboração, com dados de pesquisas de orçamentos familiares -, definiu-se um valor provisório, com base nos programas já em vigor, de modo que permitisse a implantação do novo programa.

De outro lado, estaria sendo realizado um teste-piloto em três estados do Nordeste (Pernambuco, Alagoas e Paraíba) para o desenvolvimento de um "previsor da situação de carência", a partir de uma "cesta de 38 indicadores", com variáveis presentes no cadastro, de forma a superar o critério estrito da renda.

O indicador de renda é muito fraco no cadastro, mas assim que o retiramos e consideramos os indicadores de educação, de saneamento, de habitação, etc., conseguimos fazer uma ordenação das famílias pobres naqueles municípios pesquisados muito parecida com o que fazemos em relação à renda nesse outro cadastro que criamos como grupo de controle. (BRASIL, 2003l, p. 220, grifo nosso)

"A ideia é tornar mais nítido o conhecimento sobre quem é mais pobre dentre os pobres" (BRASIL, 2003l, p. 221), isto porque, após a correção de seus problemas, o Cadastro Único deveria servir à implementação e articulação de políticas que se complementassem, como transferência de renda, capacitação profissional e microcrédito, de modo a prover aos beneficiários desses programas a saída da condição de pobreza. (BRASIL, 2003l)

Quanto ao programa unificado, de acordo com notícias da época, o governo federal pretendia lançá-lo publicamente no dia 19 de setembro de 2003, mas a demora no consenso com os estados e municípios teria levado ao seu adiamento. (BOMBIG, 2003) Apenas o nome escolhido para o novo 
programa foi divulgado: "Bolsa Família”. Nele, seriam unificados quatro dos programas de transferência de renda federais: Bolsa-Escola, Bolsa-Alimentação, Vale-Gás e Cartão Alimentação. (BOLSA-FAMÍLIA..., 2003)

O PBF foi efetivamente criado em 20 de outubro de 2003, através da Medida Provisória n.. 132. Nesse momento, confirmou-se a criação de uma coordenação centralizada para os programas federais, e isso ficou mesmo "no âmbito da Presidência da República". O documento afirma que o novo programa "tem por finalidade a unificação dos procedimentos de gestão e execução das ações de transferência de renda do Governo Federal”, onde se incluem os quatro programas citados acima (Bolsa-Escola, Bolsa-Alimentação, Vale-Gás e Cartão Alimentação) e o Cadastro Único. (BRASIL, 2003g, Art. 1ํㅡㄹ Parágrafo único) O programa se destinaria a duas categorias de beneficiários: "extremamente pobres" e "pobres", classificadas de acordo com a renda familiar per capta, estipulada em máximos de $\mathrm{R} \$ 50,00$ e de $\mathrm{R} \$ 100,00$ respectivamente. A primeira categoria ("pobreza extrema”) receberia um benefício "básico" de $\mathrm{R} \$$ 50,00, acrescido de um outro "variável”, de acordo com a composição familiar. A segunda categoria ("pobre”) receberia apenas o benefício variável, se atendesse aos requisitos da composição familiar. (BRASIL, 2003g, Art. $2^{\circ}$ )

É importante ressaltar que à época o salário mínimo, cujo valor servia de referência para seleção de beneficiários de parte dos programas unificados pelo Bolsa Família, estava em $\mathrm{R} \$ 240,00$. A linha do corte do novo programa situava-se, portanto, abaixo daquela até então estabelecida, o que confirma a opção do governo em focar essa ação sobre "os mais pobres entre os pobres". E é neste ponto que o Cadastro ganhará maior especificidade, porque o seu público continuará sendo a população de baixa renda $(\leq \mathrm{I} / 2 \mathrm{sa}$ lário mínimo), enquanto a "política de transferência de renda" se destinará a duas subcategorias dessa população (extremamente pobre e pobre). Observe-se que, com essa medida, o governo pôde manter o cadastro anterior sem desprezar o objetivo de alcançar "os mais pobres", porque não seria mais um cadastro para seleção de beneficiários de um programa especificamente.

Outros aspectos importantes devem ser ressaltados na estrutura da MP n. ${ }^{-}$132, como a atração tanto da execução da transferência quanto da sua gestão para o âmbito da Presidência. Aí se define que execução e gestão operar-se-ão juntas. Não se trata apenas de transformar vários programas num só, mas de estabelecer uma dinâmica administrativa que articula os diferentes procedimentos a eles relacionados. 
Além dos benefícios básico e variável, o $\$ 7^{\circ}$ do Art. $2^{\circ}$ cria um terceiro benefício no Programa: "benefício variável de caráter extraordinário", de duração precária, como determina o § 8 do mesmo Artigo. (BRASIL, 2003g) Embora pareça um mecanismo simples de ajuste à nova metodologia empregada na execução da transferência de renda do governo federal, uma análise mais apurada sobre essa modalidade de benefício permite vislumbrar a criação de uma espécie de "piso mínimo de renda familiar", como analisou Almeida (2004) em relação ao benefício básico do PBF, ou mesmo o estabelecimento daquele "mínimo vital" que fundamenta a noção de pobreza absoluta. (ROCHA, 2003) O mais importante a se observar, porém, é que a definição conceitual desse benefício permite realizar uma espécie de decantação do público-alvo do Programa, funcionando como o trânsito que levará à uniformização desse público, porque ao cessar a condição de elegibilidade para os programas anteriores, cessa-se também a vigência do benefício extraordinário, mantendo-se apenas o piso do PBF. Portanto, esse benefício favorece o mecanismo de tipificação da categoria "pobreza" a partir de um corte de renda rígido, confirmado na supressão da possibilidade de concessão de qualquer novo benefício senão pelo PBF. (BRASIL, 2003g, Art. $\left.9^{\circ}\right)$

Outro elemento importante de mudança encontra-se no Parágrafo Único do Art. 6o (BRASIL, 2003g), que subordina a cobertura do PBF à dotação orçamentária. Esse dispositivo contém um elemento contraditório, pois segue o caminho inverso à perspectiva de atender à totalidade das famílias pobres; ele estabelece simultaneamente uma clara distinção entre os públicos do Cadastro Único - todas as famílias de baixa renda que representam o público potencialmente demandante de assistência - e do Bolsa Família - “os mais pobres entre os pobres”, que representam o público elegível como beneficiário do programa.

\section{A IDENTIFICAÇÃO DE PROBLEMAS MÚTUOS ENTRE O BOLSA FAMÍLIA E CADÚNICO POSTULANDO SOLUÇÕES CONTÍGUAS DE CONTROLE OPERACIONAL E MONITORAMENTO DA POBREZA}

No primeiro trimestre de 2004, o TCU divulgou o resultado do primeiro monitoramento das recomendações feitas a partir da Auditoria do 
Cadastro Único em 2002. ${ }^{61}$ De forma genérica, o TCU observou que as modificações que estavam se dando sobre o Cadastro orientavam-se pela unificação dos programas, realizada com a criação do Bolsa Família, das quais serão aqui destacadas apenas as mais pertinentes à discussão em curso. Com respeito à recomendação de se criar uma "sistemática de manutenção e atualização" dos dados que desse maior autonomia aos municípios na manipulação do Cadastro, o Tribunal verificou que ela estava sendo implementanda, uma vez que a Caixa Econômica havia desenvolvido uma versão melhorada do software de entrada de dados, versão 5.0, mas advertiu quanto à persistente ausência de "procedimentos, prazos e responsabilidades" (BRASIL, 2004i, p. 4) para a operacionalização do Cadastro. Ainda assim, o TCU considerou que essa medida atendeu também à recomendação de eliminar a incompatibilidade entre diferentes versões de softwares que dificultava os procedimentos de inserção de dados, porque a instalação da nova versão exigia a desinstalação de suas antecessoras. (BRASIL, 2004i)

Quanto à recomendação de repasse de "auxílio financeiro" aos municípios para a atividade de cadastramento, o Tribunal de Contas considerou que essa medida estava em fase de implementação, com base em estudos em curso, segundo informado pelo gestor do Cadastro. Também em relação à recomendação de ampliação dos canais de comunicação com estados e municípios, o TCU considerou que a implementação estava em processo, com destaque ao que se disponibilizava em meios eletrônicos. Nesse mesmo sentido, havia a recomendação de divulgação do canal de esclarecimento de dúvidas, para cujo atendimento o MAS sinalizou com a disponibilização de um número telefônico específico e com a internet.

Quanto à recomendação de realizar um levantamento do contingente de famílias pobres a partir do Censo Demográfico 2000 (IBGE) para atualização das estimativas de pobreza e sua compatibilização ao número de formulários disponibilizados aos municípios (até então insuficiente), informou-se que foi estabelecida uma "cooperação técnica" entre o MAS e o IBGE com esse fim. Além disso, a definição de uma "linha de pobreza oficial” estaria em formulação no âmbito do IPEA, no intuito de se abandonar

61 Encontramos esse relatório do primeiro monitoramento do TCU disponível na internet em dois formatos: $p d f$ e html. O primeiro, datado de outubro de 2003 , referindo-se à data de conclusão do monitoramento, e o segundo, de março de 2004, referido à sessão de aprovação do relatório. Na referência bibliográfica, mantivemos a última data. 
o corte referenciado no salário mínimo para o público do Cadastro, considerando ainda que o critério da estimativa não limitaria mais a quantidade de formulários. (BRASIL, 2004i)

O TCU havia recomendado também a adoção de "indicadores de desempenho" do Cadastro, ${ }^{62}$ ao que o MAS respondeu parcialmente, indicando a necessidade de novos estudos, considerando as mudanças que estariam se dando no instrumento de cadastramento. Outra recomendação foi a de que a CEF realizasse depuração dos dados do Cadastro Único, em razão das duplicidades de NIS. Em atenção a ela, o TCU verificou que houve a implantação de um "módulo de auditoria" para detecção de falhas e a vinculação dos NIS dos membros da família ao de seu responsável. Além disso, o Tribunal observou também que se alterou para o modo on line a forma de acesso aos dados do Cadastro por parte dos gestores dos programas diretamente na base de dados da Caixa, não mais se utilizando media removível, evitando as diferenças entre os dados registrados e os sistematizados.

Enfim, em relação à recomendação de "crítica dos rendimentos" declarados, comparando a base de dados do CadÚnico com outras bases (RAIS e SISBEN), o TCU obteve a resposta de que estaria em desenvolvimento, no âmbito do Governo Federal, um sistema de "identificação social única do cidadão brasileiro”, o que permitiria a articulação de todos os cadastros setoriais através do NIS. (BRASIL, 2004i) Isso sugere que havia um projeto mais amplo para o NIS, de integração de outros sistemas de identificação, que não se limitaria à execução de programas sociais e não se referenciaria exclusivamente nos "pobres” do país. O desdobramento dos fatos, porém, mostrará o contrário.

Após a divulgação do monitoramento do TCU, o recém criado $\mathrm{MDS}^{63}$ publicou, em 19 de maio de 2004, a sua primeira Instrução Operacional (IO) (BRASIL, 2004g), estabelecendo procedimentos para o bloqueio de multiplicidades no Cadastro. O documento afirmava que até aquele momento já se haviam realizado duas auditorias sobre as folhas de pagamento do Bolsa

62 Taxa mensal de processamento de cadastros; taxa de famílias cadastradas pertencentes ao público-alvo; taxa de cadastros rejeitados; taxa de NIS duplicados; taxa de atingimento da meta municipal de cadastramento; grau de convergência da renda per capita média no Cadastro Único em relação ao Censo 200o; relação entre quantidade de famílias e postos de atendimento da Caixa Econômica; taxa de recursos não sacados por programa.

63 O MDS foi criado pela Lei $n^{\circ} 10.869$, de 13 de maio de 2004, alterando a estrutura ministerial definida pela Lei $n^{\circ} 10.683$, de 28 de maio de 2003 . 
Família e dos programas remanescentes, buscando identificar a presença de crianças cadastradas em mais de uma família e de titulares do PBF que recebiam também benefício de outros programas. Esse procedimento contempla claramente a determinação do TCU de se realizar uma depuração dos dados do Cadastro e confirma a instalação do "módulo de auditoria" verificado no monitoramento realizado pelo Tribunal de Contas.

Na IO nº 1/2004, o MDS admitiu a ocorrência de "vinculação de uma mesma criança a mais de um Responsável Legal no mesmo município ou em municípios distintos" (BRASIL, 2004g) e de "recebimento de benefícios em outros programas pelo mesmo Responsável Legal, simultaneamente", resultante da sobreposição de NIS, “em decorrência de inúmeros cadastramentos a que [o beneficiário] foi submetido”. (BRASIL, 2004g) Em vista disso, o Ministério procedeu ao bloqueio dos benefícios com indícios de irregularidade para averiguação e estabeleceu os procedimentos a serem seguidos pelas prefeituras. Para efetivar o bloqueio, o MDS utilizou-se de critérios distintos: no caso de criança vinculada a mais de um responsável legal, manteve o registro mais recente e bloqueou o anterior; no caso de sobreposição do Bolsa Família e outro programa, manteve o maior benefício e bloqueou os demais. Em qualquer dos casos, o gestor municipal deveria requisitar à Caixa Econômica o arquivo eletrônico contendo os dados dos respectivos beneficiários para proceder aos ajustes necessários. Coube a ele (gestor municipal) identificar cada situação e proceder à atualização dos dados, excluindo-os, complementando-os e, quando necessário, solicitando o desbloqueio do benefício. Para eventuais esclarecimentos, o Ministério relacionou, no mesmo documento (IO n⿳o 1/2004), diferentes canais de comunicação disponibilizados às prefeituras, o que atende já a outra recomendação do TCU, quando de sua Auditoria sobre o CadÚnico.

Durante o ano 2004 o TCU realizou outra auditoria, dessa vez especificamente sobre o PBF. A solicitação partiu do então Ministro Extraordinário de Segurança Alimentar, José Graziano, ainda em 2003, e dirigia-se à avaliação dos programas Cartão Alimentação, Bolsa Escola, Bolsa Alimentação, Auxílio Gás, PETI e Agente Jovem. Com a unificação de parte desses programas no Bolsa Família, a avaliação do TCU concentrou-se especificamente sobre ele. Os resultados, porém, trouxeram também questões específicas sobre o Cadastro Único, demonstrando um elevado grau de identitarização entre este e o PBF. 
A principal questão levantada nessa auditoria se refere ao controle do cumprimento das condicionalidades em saúde e educação, entendendo estas como o principal mecanismo para a emancipação social das famílias beneficiárias, e sem as quais o PBF funcionaria como simples transferência de renda. O pano de fundo dessa questão e de outras tratadas na auditoria era a ausência de regulamentação para a lei que criou o Bolsa Família (Lei no $10.836 / 2004$ ), em vista do que o PBF era interpretado como um programa incompleto em relação àqueles aos quais unificou, notadamente em relação ao Bolsa Escola e ao Bolsa Alimentação. A observação é de que "à medida que são migrados para o novo programa, os beneficiários das ações de transferência de renda anteriores deixam de ser monitorados" (BRASIL, 2004h, p. 29), por isso considera-se que, ao menos no que tange à educação, “a implantação do Bolsa-Família significou a desestruturação dos sistemas de monitoramento de condicionalidades [...], sem que novo modelo tenha tomado seu lugar”. (BRASIL, 2004h)

Diferente da auditoria anterior (sobre o CadÚnico), quando a preocupação evidenciada era a de dar mais racionalidade e precisão ao sistema de seleção dos beneficiários, em outras palavras, de tornar mais consistente a focalização dos programas de transferência de renda, agora o controle exigido é o do retorno, do controle do cumprimento da contrapartida pelos beneficiários. O não acompanhamento das condicionalidades "implica o risco de falha no alcance do objetivo de combater a pobreza e a exclusão social”. (BRASIL, 2004h, p. 30) Haveria também nesse controle um importante componente seletivo e preventivo de fraudes, uma vez que o cumprimento de condicionalidades tem um caráter ostensivo, porque obriga a frequência às instituições prestadoras de serviços públicos, o que constrange aos não pobres: "Por exemplo, freqüentar um posto de saúde público permite que o beneficiário seja identificado pelos funcionários e demais usuários, aumentando a visibilidade da correta aplicação dos critérios de inclusão”. (BRASIL, 2004h) É importante observar que, dessa perspectiva, assume-se o risco de a condicionalidade perder o caráter emancipatório que lhe foi imputado anteriormente, passando à equivalência de um certificado de pobreza, uma condição inversa, e, nesse sentido, a atribuição do NIS pode ser interpretada como uma forma de marcar e expor; de estigmatizar, enfim.

À ausência do regulamento, o TCU sugere que o controle se dê no âmbito municipal, através das escolas e postos de saúde. Para tanto, recomenda à Secretaria Nacional de Renda de Cidadania (SENARC) que "envie 
aos municípios listagem identificando as famílias e o seu perfil de condicionalidades, inclusive aquelas remanescentes do Bolsa-Escola e Bolsa-Alimentação". (BRASIL, 2004h, p. 31) Essa recomendação permite perceber a persistência da dificuldade na disponibilização dos dados do Cadastro Único para os municípios; embora o cadastramento se desse na esfera local, a sistematização dos dados era-lhes estranha, já que a geração de informações sobre o perfil das famílias cadastradas, por exemplo, competia exclusivamente ao MDS. E isso ainda, em tese, porque na realidade o Cadastro seguia sob a posse da CEF, como se verá à frente.

Outro problema compartilhado entre PBF e CadÚnico, que aparece na auditoria, é a deficiência de informações e de orientação para operação do programa. Segundo o relatório, "as principais dúvidas [dos gestores municipais] são sobre os critérios para inclusão no Bolsa-Família, a definição das cotas municipais e a sistemática de acompanhamento das condicionalidades". (BRASIL, 2004h, p. 31) Especificamente sobre os critérios de inclusão, o Bolsa Família se diferenciou dos programas anteriores - "remanescentes" - porque criou categorias próprias de beneficiários. Os pobres do PBF não são todos os que estão registrados no cadastro que os seleciona. A base das dificuldades dos gestores estava exatamente na diferenciação entre o público do Cadastro e o público do programa; um problema solúvel com a divulgação de informações corretas, mas a comunicação entre as esferas federal e municipal dava-se como que por salto, não por uma linha contínua, o que gerava esse tipo de lacuna.

A auditoria registrou ainda a falta de controle social sobre o PBF. E esse é um aspecto que também pode ser observado daquela perspectiva de desestruturação dos mecanismos que existiam anteriormente. Os programas remanescentes tinham as suas instâncias de controle, cujas prerrogativas destacavam a ratificação da listagem de beneficiários, e isso era bastante evidente, por exemplo, no Cartão Alimentação, com a criação do CGL. Mas há dois elementos que devem ser trazidos para a análise desse tópico: primeiro, o Bolsa Família juntou os programas, então, de quem seria a competência do controle? Depois, a seleção dos beneficiários agora dar-se-ia exclusivamente através do Cadastro Único, no âmbito federal; qual seria então o papel do controle nesse aspecto? É nesse sentido que o TCU mais uma vez vai destacar a ausência de regulamento, a falta de definição sobre questões críticas do programa. 
Segundo os gestores municipais, a falta de regulamentação e definição da forma de atuação do controle social por parte do MDS inibe os próprios municípios a operacionalizarem a criação dos conselhos. Sem essa definição, não se pode contar com um controle social efetivo como instrumento de monitoramento e controle do desempenho do programa. (BRASIL, 2004h, p. 37)

Quando trata especificamente sobre o Cadastro Único, a primeira questão colocada no relatório de auditoria retoma as dúvidas sobre os critérios de inclusão de beneficiários, reiterando a confusão estabelecida entre Cadastro e Programa. O relatório destaca os principais pontos abordados pelos gestores municipais: a expectativa criada pelo cadastramento; a exclusão de famílias em situação de carência nutricional, em decorrência do critério de renda autodeclarada; dificuldades na manipulação do arquivo-retorno, dentre outros. Não estava claro, por exemplo, o porquê de se incluir novos beneficiários, uma vez que famílias cadastradas desde 2002 ainda não haviam sido contempladas. Como afirmou o TCU, "essa situação revela falta de transparência dos critérios de acesso ao programa via Cadastro Único". (BRASIL, 2004h, p. 47) Isso porque, desde o início de 2003, o governo federal buscava soluções para os diversos problemas gerados na execução do Cadastro, tendo-se cogitado, inclusive, a sua extinção para criação de um novo instrumento. Com a criação do Bolsa Família, parecia confirmada a sua manutenção, mas o que se percebe a partir daí é que houve uma opção por tomar os dados de quem já era beneficiário de programas remanescentes, especialmente do Bolsa Escola, como ponto de partida para a correção do cadastro. Logo, por aí se deduz que o caminho para inserção de outros beneficiários seria necessariamente o recadastramento.

Ainda em relação ao Cadastro, outro elemento mencionado é a dificuldade do gestor local em justificar para uma outra parcela da população a sua não inclusão no programa. Trata-se das famílias com renda per capta imediatamente superior ao corte estabelecido e alcançando no máximo I/2 salário mínimo. Em verdade, esta é mais uma dificuldade dos critérios de elegibilidade inerente aos programas focalizados e que induz a um reconhecimento do Estado à condição de pobre. Do ponto de vista técnico, a definição do corte de renda do Bolsa Família, abaixo de I/2 salário mínimo, permitiu combinar a manutenção do Cadastro com a pretensão de alcançar "os mais pobres entre os pobres". Se uma das críticas que pesavam sobre o cadastro era o registro de não pobres, o corte baixo inviabilizaria que as 
famílias nessa condição fossem atendidas e avalizaria o cadastramento de outras, segundo o perfil exigido pelo programa, mesmo com um banco de dados extenso ainda não contemplado. Por outro lado, a definição desse corte levanta algumas questões sobre a eficácia dos critérios definidores da referida “condição de pobre”. Será que, por exemplo, uma família com renda per capta de $\mathrm{R}$ \$141/mês é menos pobre que outra com $\mathrm{R}$ \$140? Obviamente a fronteira que define limites entre uma e outra é extremamente frágil, e não haveria outra forma de estabelecê-la senão com um certo nível de arbitrariedade. Por outro lado, a grandeza das metas é dada certamente por definições prévias e políticas de dotação orçamentária. Decerto, podese obstar que a criação do Cadastro Único abriu a possibilidade de unificação de critérios para a delimitação do público pobre e que o Bolsa Família segmentou mais uma vez esses critérios, mas Cadastro Único e Bolsa Família têm pretensões distintas: em linhas gerais, enquanto o primeiro contempla uma base de dados sociais unificados que se constitui num instrumento para a implementação de políticas sociais, ou seja, visa agrupar e identificar numa única categoria uma diversidade de indivíduos que partilham de condições econômicas semelhantes - pessoas de "baixa renda" -, o segundo é um programa de distribuição de benefícios dirigidos segundo estratos preferenciais de assistência do Estado.

O regulamento do PBF, Decreto 5.209, de 17 de setembro de 2004, se antecipou à publicação do relatório de auditoria do TCU, mas pode-se observar que foi a própria auditoria que motivou a sua edição. Embora a divulgação dos resultados tenha se dado já ao final daquele mês (setembro de 2004), o Governo Federal teve acesso ao seu conteúdo numa versão preliminar, para que também os seus comentários frente às medidas corretivas sugeridas fossem inseridos na versão definitiva. É notória, portanto, no texto do Decreto (BRASIL, 2004a), a atenção a outras questões colocadas pelo TCU. Mas não apenas isso. Nesse momento, começa a se desenhar um novo esquema de controle sobre a operação do Cadastro Único e dos programas que o utilizarão, e, em conta disso, a delegação de competências às instâncias responsáveis por fazê-lo.

O sistema de controle de condicionalidades, à semelhança dos programas remanescentes, foi partilhado entre os Ministérios da Saúde e da Educação, sob a supervisão do MDS, o qual deveria dispor a base de dados do Cadastro Único para fins de acompanhamento, sendo a definição das diretrizes e normas remetida para ato posterior. (BRASIL, 2004a, Art. 28) 
O Decreto $\mathrm{n}^{\circ}$ 5.209/2004 flexibilizou a responsabilidade pelo acompanhamento das condicionalidades, para que pudesse ser exercido por outras instâncias federativas, desde que dispusessem das condições necessárias para tal. Corroborando essas disposições, nos dias 17 e 18 de novembro - dois meses após a edição do decreto, portanto - foram editadas as Portarias Interministeriais no 3.789 , referida às condicionalidades em educação, e ํㅡㄴ 2.509, referida à saúde, respectivamente. Assim, a frequência escolar mínima de $85 \%$ e a utilização dos serviços básicos de saúde voltam a ser imperativos para a manutenção dos beneficiários no Bolsa Família.

Além dessa medida, também a questão do controle social foi especificada no regulamento do PBF. Nele, determinou-se a criação de um conselho intersetorial para realizar o controle, permitindo-se a utilização de conselho ou instância preexistente, desde que obedecendo ao mesmo princípio. (BRASIL, 2004a, Art. 29) Diferente do que se pretendeu para o Comitê Gestor do Programa Nacional de Acesso à Alimentação (PNAA), por exemplo, as atribuições do novo conselho não incidirão diretamente no processo de seleção de beneficiários, sendo-lhe, contudo, franqueado o acesso aos formulários do Cadastro Único e aos sistemas eletrônicos referidos ao PBF (BRASIL, 2004a, Art. 32), ressaltada a divulgação ampla da relação de beneficiários pelo município. (BRASIL, 2004a, Art. 32, § 1ํㅜ) O regulamento definiu as características e atribuições da instância de controle social, mas a edição de uma portaria do MDS, em 11 de novembro de 2004, faz perceber que nem tudo foi respondido. A Portaria no 66o/2004 estabeleceu regras transitórias de fiscalização e acompanhamento do PBF, estendendo as prerrogativas dos conselhos a serem criados àqueles que os antecederam. Isso faz pensar que houve uma reconsideração acerca daquilo que o TCU chamou de "sistema de monitoramento das condicionalidades", vinculado ao programa Bolsa Escola, no sentido de restabelecer a sua operacionalidade até que as novas estruturas pudessem vigorar. (BRASIL, 2004h)

Na definição de competências, o CadÚnico será confirmado sob a gestão do MDS, no âmbito nacional, mas, obedecendo ao princípio da descentralização, contará com uma coordenação estadual e outra municipal, constituídas a partir da adesão dos entes federados ao PBF, mediante assinatura de termo com esse fim. (BRASIL, 2004a, Art. 11) No que tange especificamente ao Cadastro, a participação estadual aparece bastante difusa, limitada a "apoiar e estimular o cadastramento pelos Municípios" (BRASIL, 2004a, Art. 13, VI); é o município (e o Distrito Federal, por equivalência) que deve, 
pois, “proceder à inscrição das famílias pobres” (BRASIL, 2004a, Art. 14, II, Art. 15, II, grifo nosso), ação que compreende as atividades principais de cadastramento das famílias e de alimentação do banco de dados do Cadastro Único.

À Caixa Econômica, delegou-se a função de "Agente Operador" (BRASIL, 2004a, Art. 16), corroborando o papel desempenhado até então por essa instituição, a despeito das críticas apresentadas desde o período da transição. É possível que isso tenha se dado por força das circunstâncias, pois toda a infraestrutura eletrônica fora desenvolvida e estava sob o domínio da Caixa, tanto do CadÚnico quanto do Bolsa Escola (CadBES). Tanto o é, que o regulamento do PBF (Decreto no 5.209/2004) estabelece, dentre as atribuições da CEF, a "elaboração de relatórios e fornecimento de bases de dados necessários ao acompanhamento, ao controle, à avaliação e à fiscalização da execução do Programa Bolsa Família”. (BRASIL, 2004a, Art. $16, \S$ 1으, IV, grifo nosso)

O detalhe mais importante do Decreto n. ${ }^{\circ}$ 5.209/2004, referido ao Cadastro, diz respeito ao processo de seleção das famílias beneficiárias do PBF. Isso pode parecer tautológico, mas não o é. O CadÚnico é a porta de entrada no Programa (BRASIL, 2004a, Art. 17) para as famílias consideradas "elegíveis", ou seja, em condição de "pobreza" e "extrema pobreza". O critério é a renda per capta, mas o texto do Decreto abre o precedente para utilização de "um conjunto de indicadores sociais" (BRASIL, 2004a, Art. $\left.18, \S_{1} 1^{\circ}\right)$, a partir do próprio Cadastro, algo que não se efetivará. Além disso, esse Decreto não informa como se dará a seleção, um dado importante, uma vez que os limites para a cobertura do Programa submetem-se às dotações orçamentárias. Nem mesmo os beneficiários advindos de programas remanescentes ${ }^{64}$ têm contemplação garantida, pois deverão atender aos "critérios de elegibilidade" do novo programa, bem como à "disponibilidade orçamentária e financeira” do mesmo. (BRASIL, 2004a, Art. 18, §3º) Nesse sentido, o Cadastro funcionará como um filtro, garantindo a atenção focada nos mais pobres. A seleção de beneficiários parece dar-se no próprio sistema cadastral, sugerindo a existência de um mecanismo automatizado de escolha, mas essa operação pode entrar em conflito com a restrição orçamentária do PBF. Ao afirmar que "Os atos necessários ao processamento

64 É justamente na redação do Decreto n. ${ }^{\circ}$ 5.209/2004 que a nominação "remanescentes" é atribuída aos programas unificados no PBF. (BRASIL, 2004a, Art. $3^{\circ}, \S 1^{\circ}$ ) 
mensal dos benefícios e das parcelas de pagamento serão editados segundo regras estabelecidas em ato do [MDS]" (BRASIL, 2004a, Art. 26), o Decreto posterga essa definição, mas simultaneamente a submete ao gestor nacional, o próprio Ministério. Em outras palavras, o poder de que dispunha o município na definição de quem eram os seus pobres transfere-se, ao menos em parte, para o governo federal. "Em parte”, de fato, porque o cadastramento é de responsabilidade exclusiva do gestor local. 